\title{
A Step towards Environment Degradation Mitigation in the Manufacturing Sector of Pakistan: Do Energy Consumption, Foreign Direct Investment, and Financial Development Matter? Evidence from Symmetric and Asymmetric ARDL Approach
}

Arsalan Tanveer ( $\square$ arsalantanveer1489@gmail.com )

Nanjing University of Science and Technology China https://orcid.org/0000-0003-4519-0701

Huaming Song

Nanjing University of Science and Technology China 210094

Muhammad Faheem

Bahauddin Zakariya University

Abdul Daud

NJUST: Nanjing University of Science and Technology

Saira Naseer

Nanjing University of Science and Technology

\section{Research Article}

Keywords: Energy Consumption, FDI, Manufacturing Sector, NARDL, Pollution Halo Hypothesis, Pakistan

Posted Date: May 11th, 2021

DOl: https://doi.org/10.21203/rs.3.rs-392119/v1

License: (c) (1) This work is licensed under a Creative Commons Attribution 4.0 International License. Read Full License

Version of Record: A version of this preprint was published at Environmental Science and Pollution Research on July 27th, 2021. See the published version at https://doi.org/10.1007/s11356-021-14955-7. 


\title{
A Step towards Environment Degradation Mitigation in the Manufacturing Sector of Pakistan: Do Energy Consumption, Foreign Direct Investment, and Financial Development Matter? Evidence from Symmetric and Asymmetric ARDL Approach
}

\author{
ArsalanTanveer(Corresponding Author) ${ }^{1}$, Huaming Song ${ }^{2}$, Muhammad Faheem ${ }^{3}$, Abdul \\ Daud $^{4}$, SairaNaseer ${ }^{5}$
}

\begin{abstract}
The manufacturing sector is the backbone for the development of an economy. Numerous studies investigate the impact of aggregative energy consumption on environmental degradation by using typical econometric techniques. To correct this gap our study uses energy consumption and environmental degradation only in the manufacturing sector of Pakistan for the period 1985 to 2018. Our study also demonstrates the symmetric and asymmetric behaviour of energy consumption with carbon emissions by using a recently developed methodology byShin et al. (2014).The linearARDL result shows energy consumption and financial development intensifies environmental degradation. While FDI and globalization mitigate environmental sustainability also the results validate pollution halo hypotheses in Pakistan. However, nonlinear ARDL results confirm theasymmetric behaviour of energy consumption with $\mathrm{co}_{2}$ emission. This study employs implications for policymakers in Pakistan to consider asymmetric behavior of energy consumption as well as the installation of renewable energy sources and technological improvements in the industrial sector need to mitigate environmental sustainability. Further, there is a need to enhance globalization and FDI for Pakistan to achieve its environmental targets.
\end{abstract}

Keywords: Energy Consumption, FDI, Manufacturing Sector, NARDL, Pollution Halo Hypothesis, Pakistan.

\footnotetext{
${ }^{1}$ School of Economics and Management, Nanjing University of Science and Technology, P.R China. 210094. (Contact by Email: arsalantanveer1489@gmail.com).

${ }^{2}$ School of Economics and Management, Nanjing University of Science and Technology, P.R China 210094. (Contact by Email: Email: huaming@ @just.edu.cn).

${ }^{3}$ School of Economics BahauddinZakariya University, Multan Pakistan.

(Contact by Email: Emai faheem@bzu.edu.pk).

${ }^{4}$ School of Economics and Management, Nanjing University of Science and Technology, P.R China 210094, (Contact by Email: Email: abduldaud@njust.edu.cn).

${ }^{5}$ School of Economics and Management, Nanjing University of Science and Technology, P.R China 210094, (Contact by Email: Email: sairanaseer721@ njust.edu.cn).
} 


\section{Introduction}

Climate change and $\mathrm{CO}_{2}$ emissions are the basic component for the sustainable environment along with economic growth. It is a dilemma for developing and developed countries to maintain an inverse linkage between economic growth and carbon emissions ( $\mathrm{Du}$ and Li, 2019; Yousaf and Lin, 2020). An increase in economic growth mostly enhances the carbon emissions i.e. Environmental Kuznets Curve (EKC) hypotheses. A lot of work is done on environmental degradation and economic growth (Abbasi and Riaz, 2016; Mirza and Kanwal, 2017). The EKC hypothesis is an inverted U-shaped curve that indicates a positive link between economic growth and environmental degradation Zubair et al., (2020). The latest report published by the International Energy Agency IEA(2019)proved $\mathrm{CO}_{2}$ emissions as the highest polluting gas among the greenhouse gases. The percentage share for $\mathrm{GHG}$ is mentioned as carbon dioxide $\mathrm{CO}_{2}(90 \%)$, methane gas $\mathrm{CH}_{4}(9 \%)$ and nitrogen gases $\mathrm{N}_{2}$ with other gases constitute only (1\%)IEA (2019). Additionally, Carbon emissions have adverse effects on human health, ecosystem, species, and their habitats along with negative effects on food quality, water resources, animals, and human health. Moreover, other factors are part of the increase in carbon emissions like soil erosion, climatic situations, deforestation, urbanization, industrialization, institutional quality, agriculture, etc.(Lin and Ahmad, 2017; Jawad et al., 2017).

Carbon emission ratios from the various sectors of Pakistan are mentioned as energy (25\%), manufacturing (21\%), agriculture (24\%), vehicle combustion (14\%), other energy-related (10\%), and buildings (6\%) Economic Survey of Pakistan (2019). The global community is keen on working for the reduction of carbon emissions and environmental protection Ahmad et al.(2019). To achieve environmental sustainability all the world countries have submitted a climate change report specified as Intended National Determined Contributions (INDCs) in the conference (COP21) held in December 2015 in Paris (Lin and Raza, 2019; Abas et al., 2017).Also, Pakistan has participated and submitted the INDC in the $21^{\text {st }}$ conference (COP21) held on 29 November 2015 in Paris (Lin and Ahmad, 2017; Ahmad et al., 2019). Conforming to the "German Watch Report" in the previous 20 years, Pakistan is listed among the top ten countries where climate changes adversely affected the environment. Conferring to the climate change report of the Asian Development Bank (ADB), Pakistan's annual mean temperature raised to $0.5 \mathrm{c}$ which produced socio-economic effects on human health, reduction in crops productivity, rivers flow, droughts, heatwaves, and effects on hydropower generation (Malik et al., 2020; Abas et al., 2017). The report of "Global Climate Change Risk Index" (GCCRI) Pakistan indicates that it suffered a huge economic loss of 0.53 per unit GDP equals $\$ 3792.52$ due to rapid climatic changes from 1999 to 2018 Economic Survey of Pakistan (2019). Pakistan is focusing on modern strategies for coping with carbon emissions but it requires the adoption of modern technologies to be implanted in the agriculture, transport, manufacturing, and production sectors Ashraf et al.(2017).

The manufacturing sector is the backbone for enhancing the economic growth of any country (Lin et al, 2014; Zhang et al., 2020; Ali et al., 2019). The industrial sector plays a multiplier role 
in the economic growth of the country. Pakistan's industrial sector contributes $13.6 \%$ of the overall gross domestic product of the country. Pakistan's manufacturing sector growth in 2006 was 8.45 percent which is raised to 14 percent in the year 2020 Economic Survey of Pakistan (2019). Previously Pakistan's economic growth was agriculture-based that is gradually shifted towards the industrial-led economy. Ultimately,the manufacturing sector growth requires more energy production and more energy consumption. Consequently, produces more carbon emissions and bad environmental standards Mahmood et al. (2020). Moreover, industrialization accounts for a high percentage of carbon emissions which distracts the environmental sustainability (Meng et al., 2021; Munir Ahmad and Zhao, 2018).

Due to the significance of a sustainable environment, the link between energy consumption, carbon emissions, and economic growth has been examined by various researchers in the different sectors of Pakistan (Buhari et al., 2020; Rehermann and Pablo-Romero, 2018; Yu, Zheng, and $\mathrm{Li}, 2018$ ).It is governed that the manufacturing sector heavily relies on energy consumption and ultimately produces more carbon emissions Baz et al. (2019). Due to a lack of resources and technological advancement; Pakistan generates energy requirements by natural gas, oil, and coal. Energy consumption for the various sectors of Pakistan is given as overall the industrial sector consumes 37.7\%, transport sector $32.2 \%$, and households consume $22.2 \%$ Baloch and Suad (2018). Pakistan's industrial output is declined by $12 \%$ due to the energy crisis Mirza and Kanwal (2017). Due to the massive production of energy from fossil fuel, Pakistan has to import Oil, LNG Gas, and other resources which result in economic decline and environmental pollution (Malik et al., 2020; Y. Zhang and Zhang, 2018). The following figures shows the trends of $\mathrm{CO} 2$ emission, energy consumption, foreign direct investment, financial development and globalization in Pakistan.

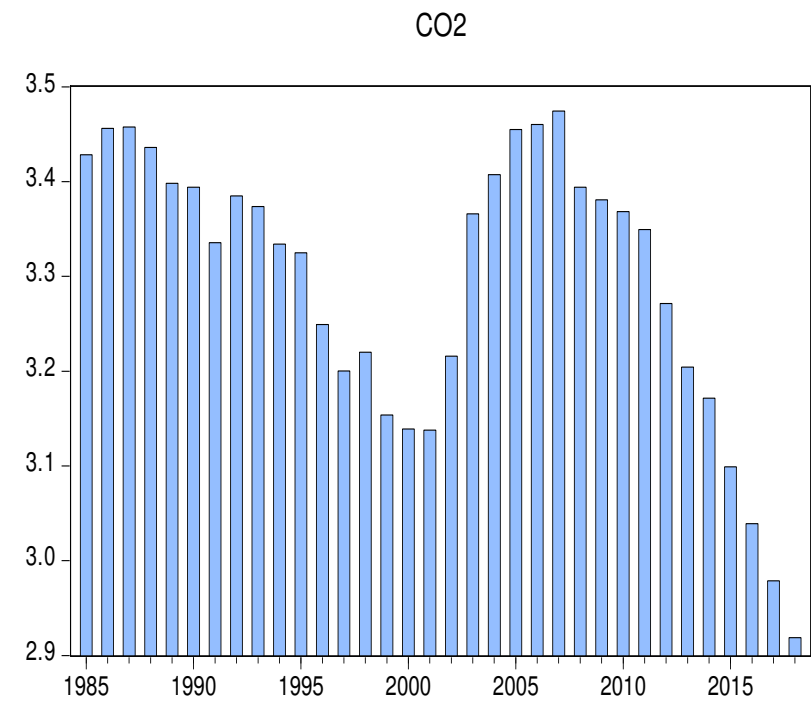

Plot \# 1: $\mathrm{CO}_{2}$ Emissions

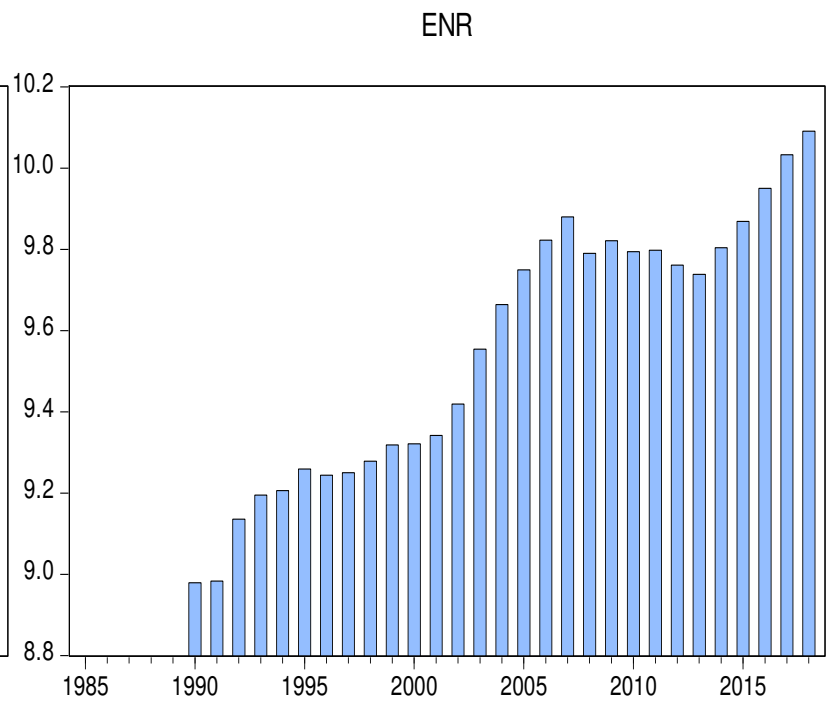

Plot \# 2: Energy Consumption 


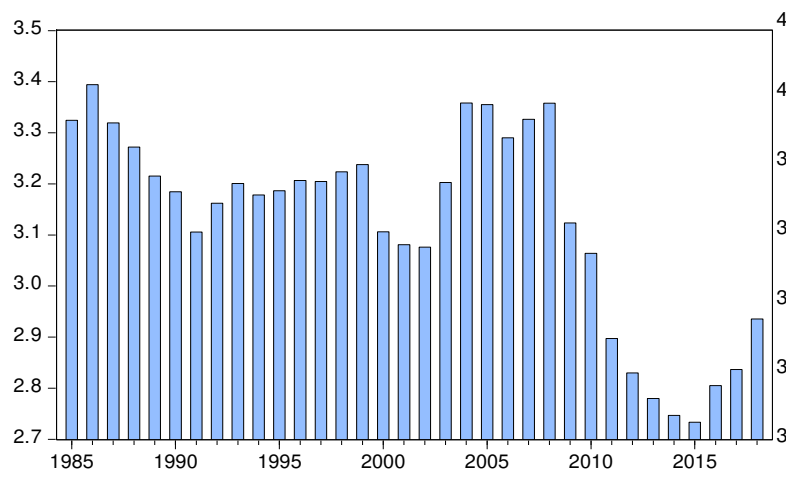

Plot \# 3: Financial Development

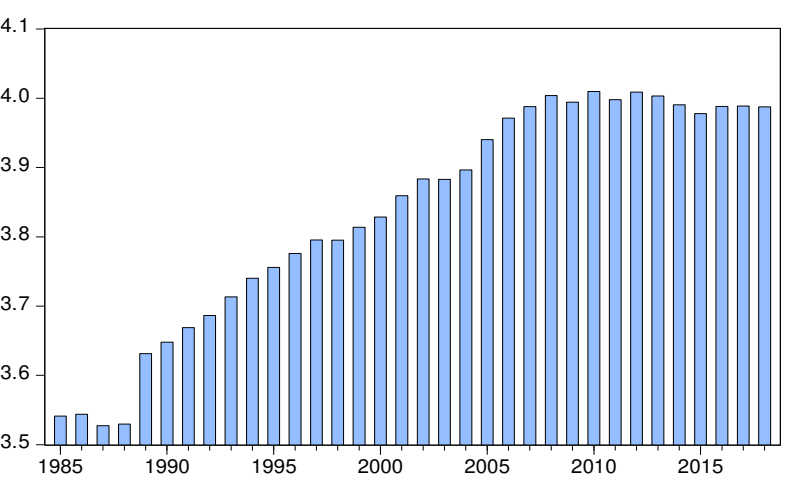

Plot \# 4: Globalization

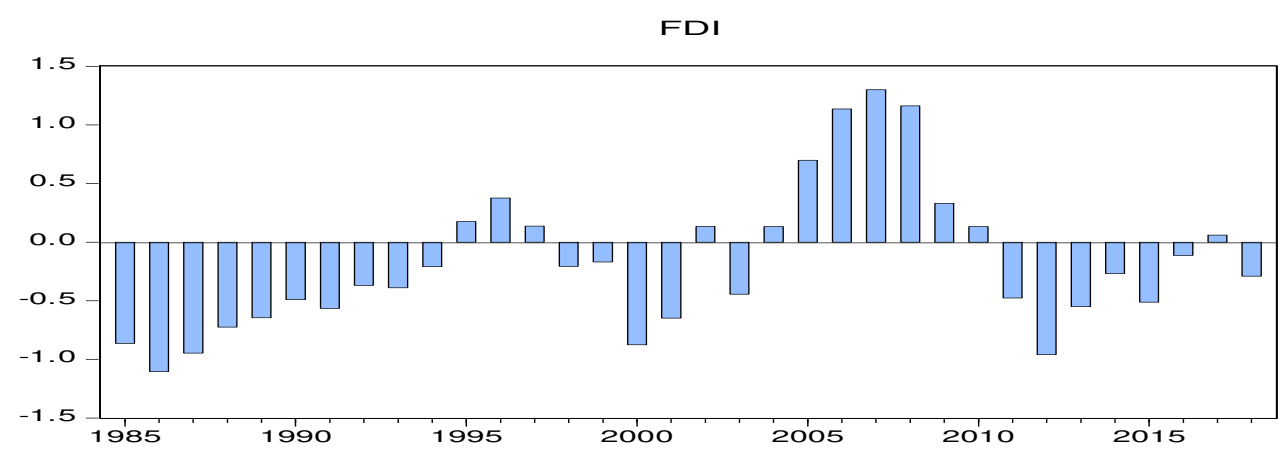

Plot \# 5: Foreign Direct Investment

One way to enhance the economic growth of the country is through foreign direct investment from other countries. The relationship between $\mathrm{CO}_{2}$ emissions and indicators of FDI (human capital, technological transfer, difference exchange rate, market size expansion) is examined by many researchers and conferred different results. (Le and Ozturk, 2020; Shahbaz.G, et al., 2019; Anser, 2019). Also, the adverse effects of FDI on $\mathrm{CO}_{2}$ emissions are governed by various authors in the context of pollution haven and pollution halo hypothesis (Nathaniel . B, Barua, et al., 2020; Destek and Okumus, 2019; Pesaran, 2014; Khan et al., 2020). The pollution haven hypothesis works in low-income countries with weak economies and less control on environmental regulations, permits developed and developing countries to reallocate their polluting manufacturing firms in those countries, and become a haven for polluters(Bakhsh et al., 2017; Shahbaz.G, et al., 2019). As a result, FDI degrades environmental sustainability in those countries. Conversely, the pollution halo hypothesis states that FDI inflow countries strictly follow the environmental regulations, and ultimately cleaner production is possible in those countries (Ur Rahman et al., 2019; Shahbaz.B et al., 2019).

The present study focused on the case of Pakistan due to tremendous factors as mentioned. Firstly, Pakistan is termed as the best place in Asia for foreign direct investments (FDI) because of its strategic location. Secondly, Pakistan and China are working on the marvellous project of "China Pakistan Economic Corridor" (CPEC) with a huge investment of \$46 billion for energy and infrastructure Ur Rahman et al. (2019). CPEC tends to open modern ways of technologies, 
new job opportunities, Foreign Direct Investments, infrastructure, corporate and private sector contracts, and energy development projects. CPEC project is termed as the highest investment project in the history of Pakistan. Thirdly, the Pakistan government is focused to create a friendly business environment for other countries and corporate businesses (Ur Rahman et al., 2019; Rasool et al., 2019). Fourthly, Pakistan has geographical importance with coastal ports, global airline routes, and infrastructure for imports and exports with border sharing countries (Iran, China, Afghanistan, and India) which provide the economical transit methods. These routes connect the Central Asian Republic Countries (CARC) and afford economical business transactions. In the future perspective, Gawadar Port (2,292 Acre Free Trade) connects trade association with Europe and Asia termed as Euro-Asia Transport Link (EATL). Additionally Gwadar Port will link the Middle East, China, and the United National Economic and Social Commission for the Asian and Pacific region (UNESCAP) for economic strength and collaboration with other countries Lin and Yousaf (2020).

Previous studies have focused on $\mathrm{CO}_{2}$ emissions and financial development of Pakistan using the ARDL approach (Abbasi and Riaz, 2016; Hussain and Ur, 2014), $\mathrm{CO}_{2}$ emissions and urbanization in the case of Pakistan with the ARDL method (Ali, Bakhsh, et al., 2019; Acheampong et al., 2019), $\mathrm{CO}_{2}$ emissions with energy consumption and economic growth in Pakistan (B. Zhang and Wang, 2017; Jawad.S, et al., 2017; Lin and Ahmad, 2017; Mirza and Kanwal, 2017; Lin and Raza, 2019), $\mathrm{CO}_{2}$ emissions among energy consumptions from the transport sector in Pakistan under ARDL technique (Baloch and Suad, 2018; Yousaf and Lin, 2020; Rasool et al., 2019), Carbon emissions and human activities in Pakistan by ARDL method Anser (2019). Apart from this literature, there is needed to focus on the manufacturing sector of Pakistan. The purpose of the paper is to seek the relationship of $\mathrm{CO}_{2}$ emissions with energy consumption, globalization, FDI, and financial developmentin the context of the manufacturing sector of Pakistan. The paper contributes to the literature in many ways: Firstly,this is theunique attempt to research the manufacturing sector of Pakistan using the ARDL and NARDL methods. Secondly, this study will prove the asymmetric behaviour of energy consumption on manufacturing output in $\mathrm{CO}_{2}$ emission. Moreover, the study gives a new direction for government officials and policymakers for the formulation of policies. This study tries to prove the validation of the Pollution Halo or Haven Hypothesis in the case of Pakistan.

The remaining structure of the paper as following: The first section of the paper is given as an introduction. The literature review is briefly explained in section two. The third section puts lights on the descriptions of the variables, comprehensive methodology, and data sources. Section four comprises empirical analysis results of the study and the last section gives the conclusion of the study.

\section{Literature Review}

The Pollution haven model was first ever offered by Pethig (1976) which explained the Ricardian model of a trade by supposing the trade between two identical countries. Neo-classical 
theory of trade works in countries that generate industrial pollution like two identical countries which have a difference in carbon pollution tax one is higher than the other. The pollution difference is the reason for trade among these countries. The pollution haven hypothesis is firstever discussed byKevinP (2008). One school of thought states that the Pollution haven theory works for developed countries to shift own polluting industries to low-income countries and save their country from environmental degradation. The FDI recipient country enhances its per capita income and pollutes its environment. The other school of thought disagrees with the first statement and says that with the enhance in FDI economic growth also improves. The improved economic position produces technological advancements in the country and reduces carbon emissions Demir and Duan(2018).

Many authors examined the positive and negative effects of foreign direct investment in the various regions of the world under pollution haven and pollution halo hypotheses (Sun.H, et al., 2020; Le.T.H, et al., 2016; Rahman et al., 2020; Shahbaz.N, et al., 2017; Hdom and Fuinhas, 2020). Some of the authors analyzed the effects of FDI for individual countries like Kazakhstan Wada et al.(2020), Pakistan (Ali.M.U, et al., 2020; Malik et al., 2020; Baloch and Suad, 2018; Abbasi and Riaz, 2016), Brazil Hdom and Fuinhas (2020), USA Shahbaz.G, et al. (2019), China (Y. Zhang and Zhang, 2018; Du and Li, 2019), Nigeria Zubair et al. (2020) and several other conducted research on the group of countries such as South Asia Rahman et al. (2020), MENA countries Shahbaz.B, et al. (2019), Sub-Saharan Africa Acheampong et al. (2019). Both the individual and group country analysis provides mixed results. The research examined by Sun.H et al. (2020) discussed the connection of $\mathrm{CO}_{2}$ emissions with environmental pollution regulations and FDI from the manufacturing sector of China for annual data from 2001 to 2007. The results indicate that both environmental regulation styles (expenditure style $\&$ investment style) and FDI produces manufacturing pollution. Also, the study validates the EKC model for manufacturing sector pollution in China.

The connection between energy consumption and $\mathrm{CO}_{2}$ emissions is governed by many authors(Zhang.Y, et al., 2019;Ahmad.A et al., 2016; Chang et al., 2016; Kasman and Duman, 2015) and found a strong positive connection in the results. The relationship between $\mathrm{CO}_{2}$ emissions and energy consumption is quiteimportant for the manufacturing sector pollutions (Tian et al., 2018; Zhu and Shan, 2020; Lin et al., 2014; Zhang et al., 2020). The study of (Ma et al., 2019;Zhang et al., 2020; Tian et al., 2018)urged thatthe highest quantity of carbon dioxide is produced by China in the world due to the high industrial pollution.

The findings of Griffin and Hammond (2019) worked on the relationship of $\mathrm{CO}_{2}$ emissions and energy consumption in the industrial sector (iron \& steel) of the United Kingdom. The iron and steel industry of the UK accounts for the highest GHG emissions about $26 \%$ and the highest energy-consuming sector. The study concluded a positive association between energy consumption and carbon emissions. To reduce carbon emissions technological innovations are required in the manufacturing sector i.e., bioenergy fuel switching, energy-efficient technologies, and carbon capture storage Griffin and Hammond (2019). The research examined by Zhang et al. 
(2020) focused on the connection between energy consumption from the manufacturing sector of China with $\mathrm{CO}_{2}$ emissions and $\mathrm{CH}_{4}$ methane gas emissions. Conferring to China's statistical yearbook (2019) manufacturing sector contributes $40 \%$ to the economic growth of the country. The results indicate that China is a manufacturing economy, which showed remarkable energy consumption in the manufacturing sector and ultimately degrades environmental sustainability. The research evaluated by Zhu and Shan (2020) explores the relationship of $\mathrm{CO}_{2}$ emissions, economic growth, and energy consumption in the industrial sector of Beijing for annual data from 2018 to 2020. The results determined that industrial growth leads China to meet the economic growth while energy consumption and reduction in carbon dioxide emissions are not truly surpassed the $13^{\text {th }}$ five-year plan of government.

Capital formation is termed as an important factor to control the nexus of environmental degradation. Financial development in a country can produce technological advancements and ultimately reduction in carbon dioxide emissions. Many researchers focused on the impact of $\mathrm{CO}_{2}$ emissions on financial development using various indicators. Akalpler and Hove (2019) analyzed positive results for gross capital formation and reduction in carbon emissions for the Indian economy. The research investigated by Javid and Sharif, 2016; Komal and Abbas, 2015) showed the association of financial development with carbon dioxide emissions and formulated a positive relationship in the context of Pakistan. Zubair et al. (2020) determined the linkage of $\mathrm{CO}_{2}$ emissions with fixed capital and found a negative result for Nigeria using annual time series data from 1980 to 2018. The research governed by Le and Ozturk (2020) determined a positive link between financial development and carbon emissions among the Emerging markets \& developing countries using data period from 1990-2014. Hence financial development increases $\mathrm{CO}_{2}$ emissions due to the establishment of the industrial sector without compliance with environmental standards.

Wang et al. (2020) examined the association of $\mathrm{CO}_{2}$ emissions and an increase in globalization various factors. First, the transport sector plays a key role in enhancing $\mathrm{CO}_{2}$ emissions by globalization. Secondly, globalization enhances industrial consumption which ultimately produces high $\mathrm{CO}_{2}$ emissions. Trade activities between countries expand industrial activities which require more energy consumption and more $\mathrm{CO}_{2}$ emissions.Shahbaz, Jawad et al. (2017) inspected the factors affecting globalization on carbon dioxide emissions for Japan. The results showed a negative relationship with globalization. In the case of Japan globalization posed strong economic impacts with technological improvements. Mehmood (2020) examined the association between $\mathrm{CO}_{2}$ emissions and globalization and found negative results in the case of Pakistan and India, on the other hand,positive relationship for Srilanka, Bangladesh, Bhutan, and Afghanistan. The research inspected byUdom et al. (2020) verified a positive connection of $\mathrm{CO}_{2}$ emissions with globalization for the Malaysian economy. The results suggest that the Malaysian economy should make ideal policies to reduce $\mathrm{CO}_{2}$ emissions through globalization. 
The review concluded that a lot of work is done on the association between carbon dioxide emissions and energy consumption in Pakistan(Baz et al., 2019;Mirzaand Kanwal, 2017; Lin and Raza, 2019;Lin and Ahmad, 2017; Chandia et al., 2018; Javid and Sharif, 2016; Zaidi et al., 2018). The idea of carbon dioxide emissions and energy consumption in Pakistan is also analyzed in various sectors like transport and vehicles(Yousafand Lin, 2020;Baloch and Suad, 2018; Lin and Yousaf, 2020; Rasool et al., 2019), financial development(Komaland Abbas, 2015; Shahzad et al., 2017), urbanization (Ali.R, et al., 2019b), Agriculture sector (Qureshi et al., 2016). All the above-mentioned studies focused on the relationship between $\mathrm{CO}_{2}$ emissions and energy consumption in the various sectors of Pakistan while so far the manufacturing sector carbon emissions have rarely been inspected byAttari et al. (2016) to a little extent. His study model was based on the carbon dioxide emissions and manufacturing sector income, apart from considering other important factors such as energy consumption, FDI, globalization, etc. which are now briefly focused on in the present study.In light of the above review, the present study endeavours to empirically analyze the effects of carbon dioxide emissions, energy consumption, FDI, globalization, and financial development in the context of the manufacturing sector of Pakistan using the linear and non-linear ARDL method.

\section{Data and Methodology} The empirical analyses utilized the annual data from the period 1985 to 2018 for the manufacturing sector of Pakistan. $\mathrm{CO}_{2}$ emissions (\% of total fuel combustion) from the manufacturing sector are used to analyze environmental quality.Total energy consumption from the manufacturing sector is obtained in kilotons of oil.Foreign direct investmentis measured in percentageof GDP.Domestic credit to the private sector is obtained in the percentage of GDP as a proxy of financial development. The data for variables $\mathrm{CO}_{2}$ emissions, FDI, Financial development, are extracted from the World Development Indicators database.Total energy consumption data is obtained from the International Energy Agency. Globalization is accessed generally, and its data is obtained from KOF Swiss Economics Institute. The details and descriptions of the variables for the present study are mentioned in Table 1.

\section{Table 1 Variable name, symbols, descriptions, and data source.}

\begin{tabular}{|c|c|c|c|}
\hline Variable & Symbol & Description & Data Source \\
\hline Carbon emission & $C B N$ & $\begin{array}{l}\text { CO2 emissions from manufacturing } \\
\text { industries and construction }\end{array}$ & World Bank \\
\hline Energy Consumption & ENR & $\begin{array}{l}\text { Manufacturing Energy Consumption } \\
\text { includes Coal, Oil, Bio-fuels, } \\
\text { Electricity, and Natural gas (kiloton of } \\
\text { oil equivalent) }\end{array}$ & $\begin{array}{c}\text { International Energy } \\
\text { Agency }\end{array}$ \\
\hline Foreign direct investment & $F D I$ & Foreign direct investment, net inflows & World Bank \\
\hline Financial Development & $F D$ & Domestic credit to the private sector & World Bank \\
\hline Globalization Index & $G L O B$ & Globalization index & $\begin{array}{l}\text { Swiss Economic } \\
\text { Institute }\end{array}$ \\
\hline
\end{tabular}




\subsection{Econometric Strategy}

In view of research work conducted in a literature review about $\mathrm{CO}_{2}$ emissions and energy consumption in the various sectors. The present study examined an econometric model with $\mathrm{CO}_{2}$ emissions from the manufacturing sector as the dependent variable. Energy consumption from the manufacturing sector and FDI are analyzed as the independent variable. Financial development and globalization index are focused as the explanatory variables in the present research. All the variables data are converted into the natural logarithm form to get smooth results. To cover the asymmetric results of positive and negative shocks of FDI, we employed the NARDL method founded by Shin (2014). The non-linear ARDL approach is the extension work of the ARDL method presented by Pesaran (2001). This technique evaluates the dynamic asymmetries raised due to the positive and negative shocks of the econometric variables between the long and short term. The importance of the NARDL approach is that it works regardless of the stationary values of the series $\mathrm{I}(0), \mathrm{I}(1)$, or a mixed stream of integration. Additionally, it works for the small sample size of the data and provides the hidden co-integration values detected by Granger (2002). Therefore, the difference between the typical ARDL and the nonlinear ARDL approach gives multiplier advantages that's why many researchers implemented the NARDL approach for econometric analysis (Ur Rahman et al., 2019; Mahmood et al., 2020; Malik et al., 2020).

The present study employed the linear-ARDL approach leading towards the non-linear ARDL method. ARDL approach is used to find the long-run and short-run relationship of the variables. ARDL approach has several advantages over the former techniques like Granger and Engle model for (two variables). Conversely, the Johansen co-integration technique works for (more than two variables). ARDL technique has various advantages over the traditional econometric methods like Johansen and Julius co-integration and Engle and Granger techniques. Firstly, the ARDL approach is employed on the small data size. Secondly, it works for the variables for stationary at level, first difference, and mixed order co-integration. Thirdly, the data generation process (DGP) works on appropriate lags of the data. Fourth, by simple ordinary least square (OLS) technique, it gives the Error Correction Term (ECM) by applying the bounding test. ECM provides separate details about the long-run and short-run interactions of the variables. Fifth, ARDL techniques give unbiased long-run results while using the dependent variable as repressors. Moreover, the ARDL approach makes the model dynamic by using different lag values.

The foundation of Pesaran (2001) is based on greater F statistic value than upper bound 1(0). Error correction term reported by Banerjee et al. (1998) provides a good way to verify the existence of a long-run relationship for variables under investigation. The ECM term must be significant and with a negative coefficient value for the validation of the long-run relationship. Finally, the ARDL techniques employ stability tests for the short-run and long-run relationships of the variables by the two criteria. These stability tests criteria's are Cumulative Sum of values 
(CUSUM) and Cumulative Sum of Square values specified by Brown et al. (1975). Further, ARDL method extended by Shin et al (2014) to check the asymmetric association of variables.

\subsection{Model Specification}

The present study examined the relationship between $\mathrm{CO}_{2}$ emissions, total energy consumption from the manufacturing sector, FDI, globalization, and financial development in the case of Pakistan. The model is specified below.

$\mathrm{CO}_{2}=f(E N R, F D I, F D, G L O B)$

Where $\mathrm{CO}_{2}$ is the carbon emissions from the manufacturing sector, ENR is the energy consumption from the manufacturing sector, FDI is the foreign direct investment net inflows, FD is the proxy of financial development which is taken in terms of domestic credit to the private sector, and GLOB is the globalization index. $\mathrm{CO}_{2}$ emissions havea strong link with energy consumption, financial development, globalization, and FDI Le \& Ozturk, (2020) and Rasool et al. (2019). The manufacturing sector's carbon emissions and energy consumption are increasing at a fast rate Gao et al. (2017) and Yang et al. (2020). The manufacturing sector mainly relies on the oil sector for energy consumption. Globalization is used as the control variable in the study to examine the international level growth in the FDI from developed countries.

$C O_{2 t}=\beta_{1}+\beta_{2} E N R_{t}+\beta_{3} F D I_{t}+\beta_{4} F D_{t}+\beta_{5} G L O B_{t}+\mu_{t}$

The coefficients $\beta_{2}, \beta_{3}, \beta_{4}$, and $\beta_{5}$ are the elasticities of $\mathrm{CO}_{2}$ emission concerning energy consumption, foreign direct investment, financial development, and globalization. The study implemented ARDL and NARDL (for asymmetric behaviour) approaches to estimate our results. This is unique methodology gives results for different lag values, works for the small size of data, convenient to use, and provides good results of estimations(Pesaran, 2001; Faheem and Chin, 2021). To estimate the above model, we apply the ARDL bounds approach by using the following specified model:

$$
\begin{aligned}
& \Delta C O_{2 t}=\alpha_{0}+\sum_{i=1}^{l} a_{1 i} \Delta C O_{2 t-1}+\sum_{i=0}^{p} \alpha_{2 i} \Delta E N R_{t-i}+\sum_{i=0}^{q} \alpha_{3 i} \Delta F D I_{t-i}+\sum_{i=0}^{r} \alpha_{4 i} F D_{t-i}+\sum_{i=0}^{s} \alpha_{5 i} \Delta G L O B_{t-i}+ \\
& +\beta_{1} C O_{2 t-1}+\beta_{2} E N R_{t-1}+\beta_{3} F D I_{t-1}+\beta_{4} F D_{t-1}+\beta_{5} G L O B_{t-1}+\mu_{t}
\end{aligned}
$$

In the above-mentioned equation, $\Delta$ indicates the first difference estimate of the concerned variable and the determined drift parameter equations $\alpha_{0}$.

The unrestricted error correction model (ECM) estimated as follows:

$$
\Delta C O_{2 t}=\alpha_{0}+\sum_{i=1}^{l} a_{1} \Delta C O_{2 t-i}+\sum_{i=0}^{p} \alpha_{2} \Delta E N R+\sum_{t=0}^{q} \alpha_{3} \Delta F D I_{t-i}+\sum_{i=0}^{r} \alpha_{4} \Delta F D_{t-i}+\sum_{i=0}^{s} \alpha_{5} \Delta G L O B_{t-i}
$$

$+\lambda E C T-1+v t_{t}$

In the above-mentioned equation, $\lambda$ defines the speed of adjusting parameter and error correction term which describes the residual values from the estimation model. Further, the non-linear model is estimated that shows asymmetric behaviour of energy consumption conforming to the 
non-linear autoregressive distributed lag technique where energy consumption is decomposed into positive and negative sections.

$$
C O_{2 t}=\beta_{1}+\beta_{2}{ }^{+} E N R^{+}{ }_{t}+\beta_{2}{ }^{-} E N R_{t}^{-}+\beta_{3} X_{t}^{332}+\mu_{t}
$$

Based on the non-linear model Equation (6), $\beta^{+}{ }_{2}$ shows energy consumption impact on $\mathrm{CO}_{2}$ emission in long runin equation (7), which is expected to be positive. And $\beta_{2}^{-}$in equation (8) indicates the reducing impact between energy consumption and $\mathrm{CO}_{2}$ emission.

$$
\beta_{2}{ }^{+} \operatorname{ENR}_{t}^{+}=\sum_{j=1}^{t} \Delta E N R_{j}^{+}=\sum_{j=1}^{t} \max \left(\Delta E N R_{j}, 0\right)
$$

$\beta_{2}^{-} E N R_{t}^{-}=\sum_{j=1}^{t} \Delta E N R_{j}^{-}=\sum_{j=1}^{t} \max \left(\Delta E N R_{j}, 0\right)$

The main objective is to examine whether energy consumption symmetrically or asymmetrically impacts $\mathrm{CO}_{2}$ emissions. Shin et al. (2014)introduced NARDL setting with the extension of ARDL as:

$\Delta C O_{2 t}=\alpha_{0}+\sum_{i=1}^{l} a_{1 i} \Delta C O_{2 t-1}+\sum_{i=0}^{p 1} \alpha^{+}{ }_{2 i} \Delta E N R_{t-i}^{+}+\sum_{i=0}^{p 2} \alpha^{-}{ }_{2 i} \Delta E N R_{t-i}^{-}+\sum_{i=0}^{q} \alpha_{3 i} \Delta F D I_{t-i}+\sum_{i=0}^{r} \alpha_{4 i} \Delta F D_{t-i}+\sum_{i=0}^{s} \alpha_{5 i} \Delta G L O B_{t-i}+$ $+\beta_{1} C O_{2 t-1}+\beta_{2}^{+} E N R_{t-1}^{+}+\beta^{-}{ }_{2} E N R_{t-1}^{-}+\beta_{3} F D I_{t-1}+\beta_{4} F D_{t-1}+\beta_{5} G L O B_{t-1}+\mu_{t}$

Equation (9) captures the positive and negative shocks of energy consumption on the $\mathrm{CO}_{2}$ emissions for the manufacturing sector of Pakistan. The long-run and short-run asymmetry is measured by $\beta_{2}{ }^{+}$and $\beta_{2}{ }^{-}, \alpha_{2}{ }^{+}$and $\alpha_{2}{ }^{-}$respectively by taking the following hypotheses:

$\mathrm{H}_{0}: \beta_{2}^{+}=\beta_{2}^{-}=0$

$H_{0}: \sum_{i=0}^{p 1} \alpha_{2 i}^{+}=\sum_{i=0}^{p 2} \alpha_{2 i}^{-}$

For all values $i=0, \ldots, p$.

\section{Results and Discussion}

\subsection{Descriptive Statistics and Correlation matrix}

Descriptive statistics and correlation of the variables are discussed in table 2. Descriptive statistics include mean, median, maximum, minimum, skewness, standard deviation, and probability values. The highest value of mean is for energy consumption and the lowest value is for foreign direct investment. Conforming to the Jarque-Bera statistics all the values are normally distributed. The values for carbon emissions, energy consumption, financial development, and globalization index are negatively skewed on the other hand FDI is positively skewed. It is seen from the summary of correlations that $\mathrm{CO}_{2}$ emissions are negatively correlated with energy consumption. Financial development has a positive correlation with $\mathrm{CO}_{2}$ emissions while negatively correlated with energy consumption. The foreign direct investment shows a positive correlation with $\mathrm{CO}_{2}$ emissions, energy consumption, and financial development. Globalization 
362 index examined positive correlation with energy consumption and FDI, while negatively 363 correlated with $\mathrm{CO}_{2}$ emissions and financial development.

\begin{tabular}{|c|c|c|c|c|c|}
\hline & $\mathrm{CO} 2$ & $E N R$ & $F D$ & $F D I$ & $G L O B$ \\
\hline Mean & 3.2690 & 9.5533 & 3.0963 & -0.0609 & 3.8825 \\
\hline Median & 3.3248 & 9.6639 & 3.1619 & -0.2062 & 3.8964 \\
\hline Maximum & 3.4745 & 10.090 & 3.3581 & 1.2997 & 4.0095 \\
\hline Minimum & 2.9188 & 8.9789 & 2.7334 & -0.9601 & 3.6479 \\
\hline Std. Dev. & 0.1461 & 0.3267 & 0.1936 & 0.5761 & 0.1199 \\
\hline Skewness & -0.6554 & -0.1695 & -0.5557 & 0.8698 & -0.5211 \\
\hline Kurtosis & 2.6386 & 1.7061 & 2.1296 & 3.2241 & 1.8630 \\
\hline Jarque-Bera & 2.2343 & 2.1619 & 2.4083 & 3.7179 & 2.8747 \\
\hline Probability & 0.3272 & 0.3392 & 0.2999 & 0.1558 & 0.2375 \\
\hline Sum & 94.8017 & 277.0463 & 89.7949 & -1.7663 & 112.5927 \\
\hline Sum Sq. Dev. & 0.5982 & 2.9902 & 1.0496 & 9.2951 & 0.4027 \\
\hline Observations & 29 & 29 & 29 & 29 & 29 \\
\hline $\mathrm{CO} 2$ & 1 & & & & \\
\hline ENR & -0.251 & 1 & & & \\
\hline$F D$ & 0.656 & -0.411 & 1 & & \\
\hline FDI & 0.433 & 0.310 & 0.562 & 1 & \\
\hline$G I$ & -0.194 & 0.953 & -0.415 & 0.278 & 1 \\
\hline
\end{tabular}

364

\subsection{Unit Root Test}

ARDL approach works if the variables are stationary at the level and first difference. However, the study of Ouattara (2004) examined that ARDL does not accept the stationary values of the variables at the second difference I(2). Due to this reason, all the variables of the study are checked by the unit root test that none of the variables is stationary at $\mathrm{I}(2)$ difference. For the sake of unit root test two tests are implemented that are Augmented Dickey-Fuller test (ADF), and the Phillips-Peron test (PP). All the variables of the study found stationary at first difference. Details of the unit root test are mentioned in Table 4.

\begin{tabular}{lcc|cc}
\hline Table 4 Unit root tests: & \multicolumn{3}{c}{ Level } & \multicolumn{2}{c}{ First difference } \\
\cline { 2 - 5 } Variables & $\boldsymbol{A D F}$ & $\boldsymbol{P P}$ & $\boldsymbol{A D F}$ & $\boldsymbol{P P}$ \\
\hline Log $\mathrm{CO}_{2}$ & 2.957110 & -2.954021 & $-2.957110^{*}$ & $-2.957110^{*}$ \\
Log FDI & -2.963972 & -2.954021 & $-2.957110^{*}$ & $-3.653730^{* *}$ \\
$\log \mathrm{FD}$ & -2.957110 & -2.954021 & $-2.957110^{*}$ & $-3.653730^{* *}$ \\
$\log \mathrm{ENR}$ & -2.981038 & -2.981038 & $-3.724070^{* *}$ & $-2.986225^{*}$ \\
$\log \mathrm{GLOB}$ & -2.105256 & -2.195449 & $-3.653730^{* *}$ & $-2.957110^{*}$ \\
\hline
\end{tabular}

Note: *and ** for $5 \%$ and $1 \%$ respectively.

\subsection{ARDL Bound Test Results}

Incorporating the results from F-statistic and bound test values from table 5, it is clear that there is a long-run relationship among the variables of the present study for equation (2). F-statistic 
values in table 5 are above than the upper critical values of Narayan (2005) table at constant values and significant. Another way of examining the long-run relationship of the variables is through the error correction term. It is commended that if the error correction term gives a significant statistic value with a negative sign Pesaran, (2001) validates the existence of a longrun association of variables.

\begin{tabular}{ccccc}
\hline \multicolumn{4}{l}{ Table 5: Bounds test estimates: $(\boldsymbol{A R D L})$} & \\
\hline \multicolumn{2}{c}{ F-bounds test statistic } & \multicolumn{2}{l}{ Null hypotheses: No level relationships } \\
\cline { 2 - 5 } & & Significance & I(O) Bound & I(1) Bound \\
\hline F-statistic & $14.938^{* *}$ & $10 \%$ & 2.45 & 3.52 \\
$k$ & 4 & $5 \%$ & 2.86 & 4.01 \\
& $2.5 \%$ & 3.25 & 4.49 \\
& $1 \%$ & 3.74 & 5.06 \\
\hline
\end{tabular}

Note: $*, * *, * * *$, and $* * * *$ for $10 \%, 5 \%, 2.5 \%$ and $1 \%$ respectively.

\subsection{Linear ARDL Estimation Results}

Long-run and short-run dynamics are examined in Table 6. The ARDL results for the relationship of $\mathrm{CO}_{2}$ emissions is significant and positive with total energy consumption for both the long and short-run in the scenario of the manufacturing sector of Pakistan, thus suggests that an increase in energy consumption degrades the environment badly in the short and long-run. Our results are in line with the previous work of Munir Ahmad and Zhao (2018) in China, Pata (2018) for Turkey, Shahbaz.G, et al. (2019) for the United States of America, (A. Ahmad et al., 2016) for India, Lin and Raza, (2019) and Mirza and Kanwal (2017) for Pakistan. Previously, Pakistan's economy was based on agriculture which is gradually shifted toward an industrial economy. The development of the manufacturing sector in Pakistan produces environmental degradation. Pakistan is still based on conventional sources $(80 \%)$ for energy production like Coal, Natural Gas, and Oil, which badly pollutes the environment. As the global economies are focusing on renewable energy production mechanisms, the government of Pakistan should need to invest in renewable energy resources to mitigate the climate-changing effects.

In the case of financial development there exists a positive significant relationship with $\mathrm{CO}_{2}$ emissions in both the and long and short-term. Our results support the previous researches conducted by Abbasi and Riaz (2016) in the case of Pakistan, Manzoor Ahmad et al. (2019) for China, Le and Ozturk (2020) for Emerging markets and developing countries EMDCs, Pata (2018) for Turkey, and Ahmad.N and Du (2017) for Iran. The results indicate that the increase of financial development in Pakistan would enhance the $\mathrm{CO}_{2}$ emissions in the short and long-run. Financial development improves the purchasing power of the communities. Financial development provides modern ways of investments in various projects and industrialization development. Pakistan is a country that is based on old technologies in the transportation, energy production, and industrialization sector which deteriorate environmental sustainability.

For FDI and $\mathrm{CO}_{2}$ emissions our results showed a significant negative relationship in the long-run and a significant positive relationship in short term. The findings revealed that $1 \%$ increase in 
FDI inflows decreses $\mathrm{CO}_{2}$ emissions by $0.626 \%$. Our results are the same asAcheampong et al. (2019) for Sub-Saharan African countries, Zubair et al. (2020) for Nigeria, and Zakaria \& Bibi (2019) for South Asia. Also, the long-term positive results validate the existence of the pollution halo hypothesis in Pakistan. The short-run findings indicate a significant positive association between FDI and $\mathrm{CO}_{2}$ emissions. In short-run FDI imparts bad impacts on the environment but in the long-run with the continuous inflow of FDI will improve the financial development which ultimately provides better conditions for improvements in production technologies of Pakistan. Comparative findings demonstrated that FDI inflow will improve sustainable technologies and reduce $\mathrm{CO}_{2}$ emissions. The long-run result of FDI suggests that Pakistan is moving towards good policies for environmental sustainability. Additionally, the present study validates the pollution halo hypothesis for Pakistan. On the other hand, some authors find a positive relationship between FDI and $\mathrm{CO}_{2}$ emissions (pollution haven) in the various regions of the world like $\mathrm{Y}$. Zhang and Zhang (2018) for China, Shahbaz.B et al. ( 2019) for Middle-East and North African countries (MENA), and (Baloch \& Suad, 2018; Malik et al., 2020) for Pakistan.

The results demonstrated that globalization has a significant negative relationship with $\mathrm{CO}_{2}$ emissions in both the short and long-run. Surprisingly our results are consistent with the studies i.e.,Shahbaz, Kumar et al. (2019) for 87 countries of the world including high developed, medium developed, and low developed countries, You and Lv (2018) for 83 world countries,Shujah-ur-Rahman et al. (2019) for Central and European countries, Zaidi et al. (2019)for Asia Pacific counties,Mehmood(2020) showed the negative relationship of globalization and $\mathrm{CO}_{2}$ emissions for Pakistan and India, Shahbaz, Jawad et al. (2017), and Umar et al. (2020)for China.The justification of the negative association of $\mathrm{CO}_{2}$ emissions with globalization in Pakistan suggests that globalization reduces $\mathrm{CO}_{2}$ emissions with technological advancements and expert manpower. Moreover, Pakistan is adopting modern ways of energy production, technological improvements, and economic corridors. CPEC project is one of the milestones for Pakistan that is a live example of globalization. Conforming to the CPEC project many energy productions, road infrastructure, and development projects are initiated in Pakistan.

Table 6: Long-run and Short-run dynamics estimates (ARDL)

\begin{tabular}{|c|c|c|c|c|}
\hline \multicolumn{5}{|l|}{ Long-run estimates } \\
\hline Variables & Coefficient & Std. Error & t-Statistic & Prob. \\
\hline$E N R$ & $3.037 * * *$ & 0.431 & 7.040 & 0.005 \\
\hline$F D$ & $4.224 * * *$ & 0.353 & 11.942 & 0.001 \\
\hline$F D I$ & $-0.626 * * *$ & 0.098 & -6.385 & 0.007 \\
\hline$G L O B$ & $-6.411 * * *$ & 0.879 & -7.288 & 0.005 \\
\hline CONSTANT & $-13.737 * * *$ & 1.887 & -7.277 & 0.005 \\
\hline \multicolumn{5}{|l|}{ Short-run estimates } \\
\hline Variables & Coefficient & Std. Error & t-Statistic & Prob. \\
\hline$D(E N R)$ & $1.116 * * *$ & 0.113 & 9.855 & 0.002 \\
\hline$D(E N R(-1))$ & 0.017 & 0.182 & 0.095 & 0.929 \\
\hline$D(\operatorname{ENR}(-2))$ & $-0.610 * *$ & 0.202 & -3.020 & 0.056 \\
\hline
\end{tabular}




\begin{tabular}{ccccc}
$D(E N R(-3))$ & -0.293 & 0.140 & -2.085 & 0.128 \\
$D(F D)$ & $0.740 * * *$ & 0.112 & 6.593 & 0.007 \\
$D(F D(-1))$ & $-1.418 * * *$ & 0.202 & -7.013 & 0.006 \\
$D(F D(-2))$ & $0.292 * *$ & 0.084 & 3.449 & 0.040 \\
$D(F D(-3))$ & $-1.443 * * *$ & 0.213 & -6.772 & 0.006 \\
$D(F D I)$ & $0.085 * *$ & 0.029 & 2.916 & 0.061 \\
$D(F D I(-1))$ & $0.133 * * *$ & 0.021 & 6.273 & 0.008 \\
$D(F D I(-2))$ & $0.099 * *$ & 0.028 & 3.499 & 0.039 \\
$D(F D I(-3))$ & $0.116 * * *$ & 0.022 & 5.080 & 0.014 \\
$D(G G L O B)$ & $-7.069 * * *$ & 1.330 & -5.313 & 0.013 \\
$D(G L O B(-1))$ & $6.956 * * *$ & 0.945 & 7.355 & 0.005 \\
$D(G L O B(-2))$ & $-6.495 * * *$ & 1.060 & -6.125 & 0.008 \\
$D(G L O B(-3))$ & -0.466 & 0.473 & -0.985 & 0.397 \\
$E C T$ & $-0.626 * * *$ & 0.112 & -5.587 & 0.011 \\
\hline
\end{tabular}

438

439

440

441

442

*Shows $10 \%, * *$ Shows $5 \%$, and $* * *$ Shows $1 \%$ significance level, respectively.

\subsection{Diagnostic Tests Results}

Diagnostic results are demonstrated Table 7 that shows the estimated model is free from issues like heteroscedasticity, autocorrelation and model is structurally stable.

\begin{tabular}{lc}
\hline Table 7: Diagnostic Tests & \\
\hline Diagnostic tests & Statistics \\
\hline$R^{2}$ & 0.999 \\
Adj $R^{2}$ & 0.995 \\
$D$. W Stat & 2.588 \\
LM test & $14.46746(0.182)$ \\
J.B test & $0.230046(0.891)$ \\
Hetro test & $1.552552(0.474)$ \\
Ramsey reset test & $0.006827(0.9417)$ \\
\hline
\end{tabular}

443

Note: P-value is in parenthesis ( ).

444

445

446
However, CUSUM and CUSUMQ indicated stability in our model showed in plots 6 and 7.
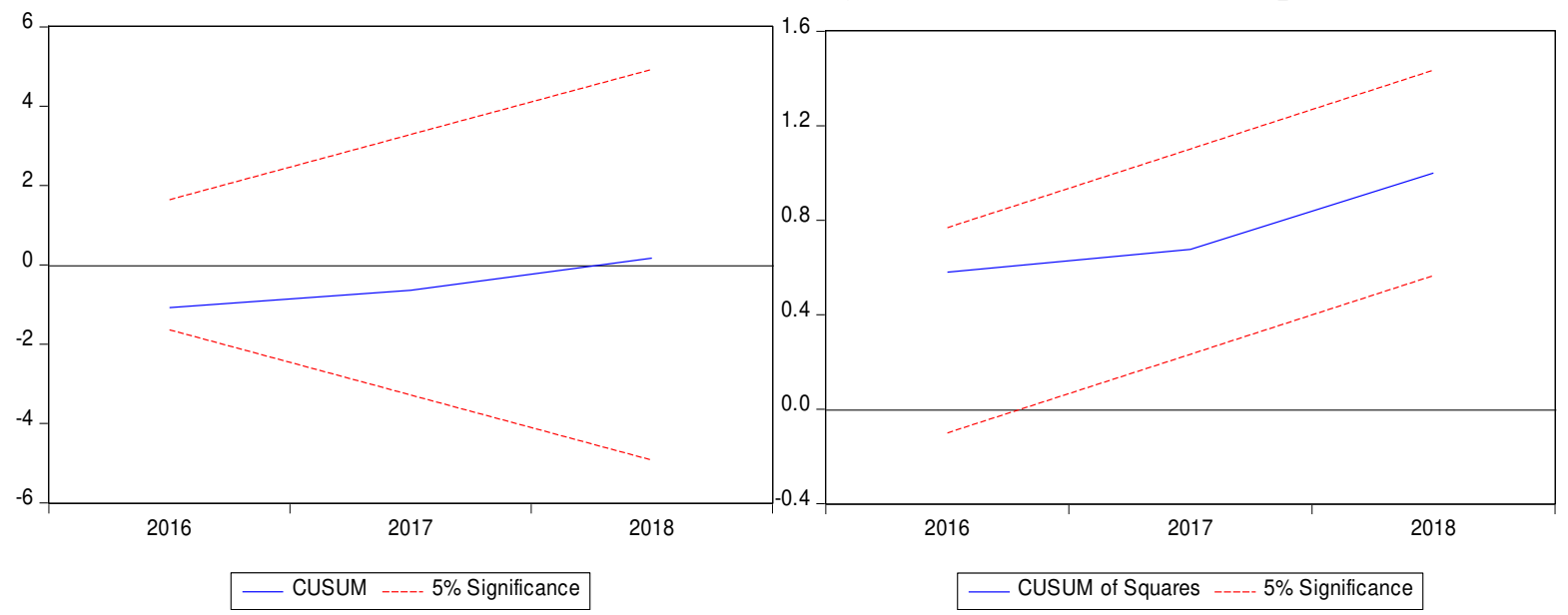

Plot \# 7: CUSUMQ 


\subsection{Linear ARDL Estimation Results}

The non-linear ARDL bound test results are represented in Table 8 which shows the Fstatistic value is significant at a $5 \%$ level and greater than the upper bound that is surety of long-run association.

Table 8: Bounds test estimates (NARDL)

\begin{tabular}{ccccc}
\hline \multirow{2}{*}{ F-bounds test statistic } & \multicolumn{3}{c}{ Null hypotheses: No level relationships } \\
\cline { 2 - 5 } & & Significance & I(0) Bound & I(1) Bound \\
\hline F-statistic & $11.0555^{* *}$ & $10 \%$ & 2.75 & 3.79 \\
$k$ & 5 & $5 \%$ & 3.12 & 4.25 \\
& & $2.5 \%$ & 3.49 & 4.67 \\
& & $1 \%$ & 3.93 & 5.23 \\
\hline
\end{tabular}

Note: $* * *, * * * *$, and $* * * *$ for $10 \%, 5 \%, 2.5 \%$ and $1 \%$,respectively.

The non-linear ARDL results for the long and short-run are represented in Table 9. The long-run results declare a significant positive estimation for an increase in energy consumption and also positive for a decrease in energy consumption with insignificant value. The results of estimated elasticity for both increase and decrease suggest that $1 \%$ increase in $\mathrm{CO}_{2}$ emissions makes (0.4146) percent energy consumption, while a decrease in value is insignificant. The results suggest that an increase in energy consumption produces more $\mathrm{CO}_{2}$ emissions also; a decrease in energy consumption gives positive insignificant results. Pakistan needs to focus on the energy consumption sources which require moving from non-renewable energy resources towards renewable energy sources. Financial development shows negative insignificant results. FDI imparts a negative significant relationship with $\mathrm{CO}_{2}$ emissions, $1 \%$ increase in FDI reduces 0.15 percent of $\mathrm{CO}_{2}$ emissions. The negative relationship of FDI shows the validation of the Pollution Halo hypothesis in the case of Pakistan. Our results for the pollution halo hypothesis are similar for Repkine and Min(2020) foreign enterprises in China, Zubair et al. (2020) for Nigeria,Vadlamannati et al. (2009) for BRICS countries, and Zakaria and Bibi, (2019) for South Asian countries. In contrast, some studies proved the pollution haven hypothesis in Pakistan (Kamran et al. 2019;Malik et al. 2020). The reason for validation of the Pollution Halohypothesis in Pakistan is that the country is much more focused on environmental sustainability, and adopting strict measures for improvements in technology. Globalization significantly increases $\mathrm{CO}_{2}$ emissions in the case of Pakistan.

On the other hand, short-run results for positive and negative energy consumption show that positive energy consumption significantly enhances $\mathrm{CO}_{2}$ emissions, however, negative energy consumption has insignificant positive results. Financial development shows negative insignificant results, FDI shows positive significant results, and globalization gives significant positive results for Pakistan. In the next, it is determined that a significant error correction term with a negative coefficient validates the existence of the long-run relationship between variables 
480 Pesaran (2001). The ECT obtained (-0.4434) gives negative and significant results for non-linear 481 ARDL.

Table 9: Short and Long-Run dynamic estimates (NARDL)

\begin{tabular}{|c|c|c|c|c|}
\hline \multicolumn{5}{|c|}{ Long Run Coefficients } \\
\hline Variable & Coefficient & Std. Error & t-Statistic & Prob. \\
\hline$\overline{E N R^{+}}$ & $1.4146 * * *$ & 0.2542 & 5.5638 & 0.0000 \\
\hline$E N R^{-}$ & 0.4104 & 0.7320 & 0.5606 & 0.5828 \\
\hline$F D$ & -0.1316 & 0.1620 & -0.8122 & 0.4285 \\
\hline$F D I$ & $-0.1572 * * *$ & 0.0443 & -3.5434 & 0.0027 \\
\hline$G L O B$ & $4.6080 * * *$ & 0.6169 & 7.4688 & 0.0000 \\
\hline$C$ & $-12.6535 * * *$ & 2.2488 & -5.6266 & 0.0000 \\
\hline TREND & $-0.1326 * * *$ & 0.0130 & -10.1646 & 0.0000 \\
\hline \multicolumn{5}{|c|}{ Short Run estimates } \\
\hline Variable & Coefficient & Std. Error & t-Statistic & Prob. \\
\hline$\overline{D\left(E N R^{+}\right)}$ & $1.3642 * * *$ & 0.2019 & 6.7555 & 0.0000 \\
\hline$D\left(E N R^{-}\right)$ & 0.1820 & 0.2951 & 0.6168 & 0.5460 \\
\hline$D(F D)$ & -0.0583 & 0.0712 & -0.8197 & 0.4244 \\
\hline$D(F D I)$ & $-0.0349 * * *$ & 0.0148 & -2.3543 & 0.0317 \\
\hline$D(G L O B)$ & 0.4758 & 0.5763 & 0.8254 & 0.4212 \\
\hline$D(T R E N D())$ & $-0.0588 * * *$ & 0.0167 & -3.5097 & 0.0029 \\
\hline$E C T$ & $-0.4434 * * *$ & 0.1309 & -3.3860 & 0.0038 \\
\hline
\end{tabular}

482

483

484

485

486

487

488

*Shows $10 \%$, **Shows $5 \%$, and ***Shows $1 \%$ significance level, respectively.

Diagnostic test estimates are presented in Table 10 that shows model is clear from all problem. The model's stability is verified by CUSUM and CUSUMQ in Plot 8 and 9 respectively. Both the graphs are stable and remained in boundary lines.

Table 10: Diagnostic Tests (NARDL)

\begin{tabular}{lc}
\hline Diagnostic tests & Statistics \\
\hline$R^{2}$ & 0.235 \\
Adj $R^{2}$ & -0418. \\
LM test & $2.1619(0.152)$ \\
J.B test & $0.0657(0.967)$ \\
Hetro test & $0.5036(0.863)$ \\
Ramsey reset test & $1.7323(0.1037)$ \\
\hline
\end{tabular}

Note: P-value is in parenthesis ( ).

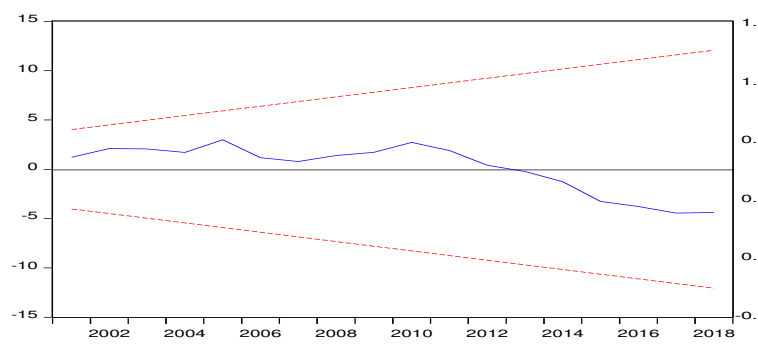

Plot \# 8: CUSUM (NARDL)

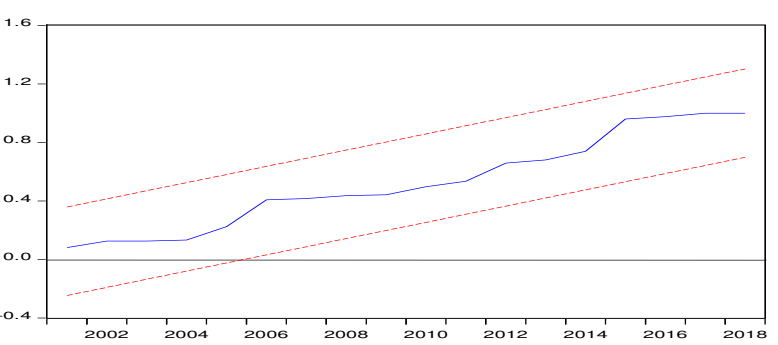

Plot \# 9: CUSUMQ (NARDL) 
Additionally, the results of the Wald test in Table 11 determine that long estimated null hypotheses of the symmetric are accepted, but short-run does not exists. Verifying the existence of long-run effects of energy consumption. Additionally, the dynamic cumulative multiplier graph is obtained for positive and negative shocks for energy consumption.

\begin{tabular}{|c|c|c|c|}
\hline \multicolumn{4}{|c|}{ Table 11: Non-Linear Wald test } \\
\hline Test & F-statistic & Probability & Decision \\
\hline $\mathrm{W}_{\mathrm{LR}}$ & 6.7678 & 0.0167 & Long-run asymmetry association exists \\
\hline $\mathrm{W}_{\mathrm{SR}}$ & 1.0308 & 0.3215 & Short-run asymmetry association does not exists \\
\hline
\end{tabular}

Note: $\mathrm{W}_{\mathrm{LR}}$ donates the Wald test for long-run symmetry hypotheses testing, and $\mathrm{W}_{\mathrm{SR}}$ represents the Wald testing results for short-run symmetry hypotheses evaluation.
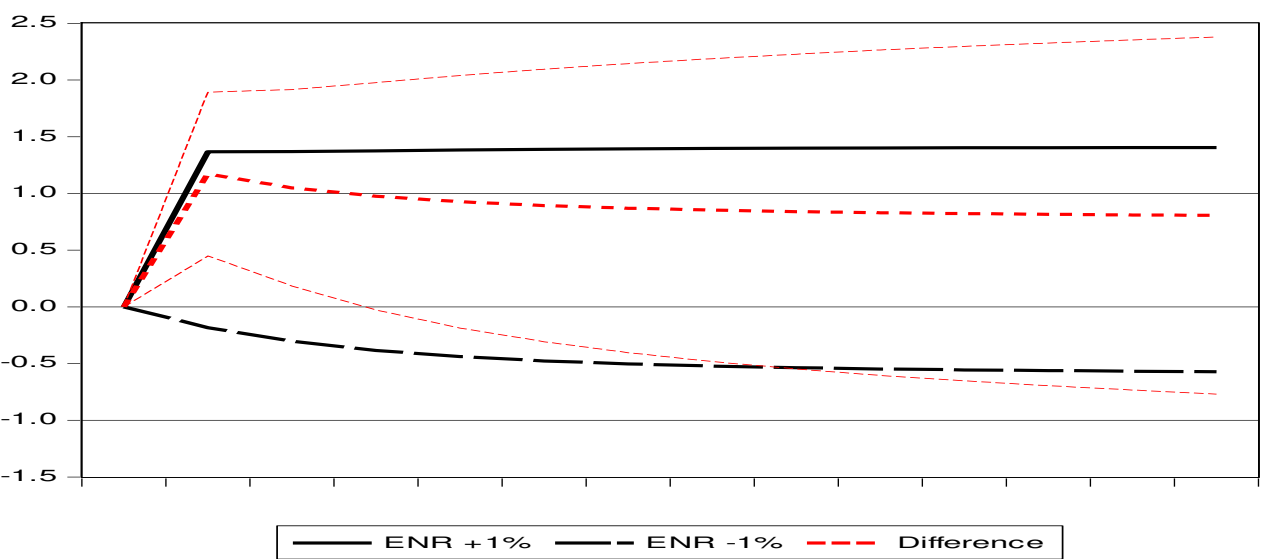

Plot \# 10: Cumulative effects of Energy Consumption on $\mathrm{CO}_{2}$ Emissions.

\section{Conclusion and Policy Implications:}

Our study examined the symmetric and asymmetric effect of energy consumption with environmental degradation in the manufacturing sector of Pakistan with foreign direct investment, financial development, and globalization as control variables for the period 1985 to 2018. The paper made a unique attempt to focus on the manufacturing sector of Pakistan apart from past work which is done on the various other sectorslike transport, energy consumption, and financial development(Abbasi and Riaz, 2016;R. Ali et al., 2019a;Bin Zhang and Wang, 2017;Baloch and Suad, 2018;Rasool et al., 2019;Anser, 2019;Yousaf and Lin, 2020;Komal and Abbas, 2015;Lin and Raza, 2019;Shahzad et al., 2017;Mirza and Kanwal, 2017).The ARDL results of the study shows that energy consumption significantly shows positive relationship with $\mathrm{CO}_{2}$ emissions both in long and short-run. In terms of energy consumption, Pakistan needs to move towards updated energy sources i.e. renewable energy sources like solar energy on large scale with cheap costs. In case of FDI, $\mathrm{CO}_{2}$ emissions showed a significant negative relationship for FDI inflows in long run and show significant positive results in the short-run. The results for the validation of the pollution halo hypothesis for FDI suggest that Pakistan is taking good initiatives for environmental sustainability. Moreover, Pakistan's vision (2018) focused on the modern ways of energy production, mitigation of climate change, and self-sufficient in energy 
requirements. The government of Pakistan has initiated many environmental sustainability activities. First, it launched an Eco-system restoration initiative for moving Pakistan to green environment and adopting climate friendly strategies. Second, "Clean Green Cities Index" is operated in the 20 big cities where no use of plastic bag is strictly followed. Due to this project burning of plastic bags is strictly reduced to a great extent. Third, it established a National Committee on Establishment of Carbon Market (NCECM). Fourthly, under a big environmental friendly project launched in 2017 "Green Pakistan" by which 100 million trees are to be planted till the year 2021 Economic Survey of Pakistan (2019). Financial development determines significant positive association with carbon emissions both in long and short-term. Pakistan requires to working on the technological improvements with the financial development. In terms of globalization, it gives a significant negative relationship with $\mathrm{CO}_{2}$ emissions both in the short and long-term. This implies that globalization improves Pakistan's environmental conditions. As Pakistan is a developing country, so it needs to focus on globalization to become a developed nation.

The asymmetric results of the study focused on the positive and negative shocks of energy consumptions in the manufacturing sector of Pakistan with $\mathrm{CO}_{2}$ emissions. Our results indicate that in the long-run increase in energy consumption significantly enhances carbon emissions while in the short-run decrease in energy consumption insignificantly increases $\mathrm{CO}_{2}$ emissions in the manufacturing sector of Pakistan. The study results are in line with R. Ali et al. (2019b) for Pakistan, Le and Ozturk (2020) for Emerging markets and developing countries (EMDCs), and Munir Ahmad and Zhao(2018) for China. Financial development gives insignificant negative results with carbon emissions both in the short and long-run. In the case of FDI asymmetric results are in line with symmetric that FDI mitigates environmental sustainability significantly both in the short and long-term. The results for FDI are consistent with the study of Zubair et al. (2020) for Nigeria, and Zakaria and Bibi (2019) for South Asian countries. Conversely, for globalization, asymmetric results indicate globalization shows a significant positive relationship with $\mathrm{CO}_{2}$ emissions in the long-term, while in the short-run globalization gives positive insignificant results.

Pakistan should provide subsidies atthegovernment level for renewable energy installation projects to reduce the energy crisis and sustainable energy productions for the manufacturing sector. The government should make standards for the manufacturing sector technological improvements and environmentally friendly production processes. Transformation towards renewable energy sources will improves the efficiency of the manufacturing sector with low-cost products. The policymakers should focus on the financial development structures to strengthen renewable energy productions. The government of Pakistan and bureaucrats should involve technical professionals for initiating modern technologies for the production sector. The proper utilization of financial resources will make Pakistan's Asian Tiger in the Asian region of the world. The policymakers in Pakistan should reserve some specific budget for the technological advancements in the manufacturing sector of Pakistan to get rid of the energy crisis and 
557 environmental sustainability. Right now, Pakistan formulated good strategies for the utilization

558 of FDI inflows which make Pakistan a pollution halo country. Still, Pakistan needs to work to 559 enhance the FDI inflows by creating friendly relationships with neighboring countries. Most of

560 the developed countries of the world make environmental improvements through high inflows of 561 investments. Pakistan launched an exemplary economic corridor project with China known as

562 the CPEC project. China Pakistan's economic corridor is a big example of globalization. The 563 policymakers in Pakistan need to get maximum benefits for the development in the 564 manufacturing sector and renewable energy mix productions through this project.

565 Acknowledgements:

566 This paper is contributed by the first author (ArsalanTanveer) and is part of the PhD dissertation. 567 He is thankful to the Chinese Scholarship Commission (CSC), and the Ministry of Education 568 (MOE) China for awarding the scholarship and provided a marvellous opportunity to get higher 569 education. The author is grateful to his research Supervisor Professor Dr. Huaming Song, 570 author's parents, friends and teachers whose efforts able him to do such work.

571

572 Declaration of Competing Interest:

573 The authors declare that there is no financial interest and competition among each other that 574 influence the work reported in the study.

\section{$575 \quad$ Ethical Approval:}

576 It is stated that the manuscript is only submitted in ESPR. The submitted manuscript is original 577 and not forwarded any where for proof reads or other. ESPR is authorized to verify plagiarism of 578 the manuscript.

579 Consent to Publish:

580 All the authors are agreed to submit the manuscript with affilations of institutes mentioned in the 581 manuscript, also agreed to submit in ESPR.

582 Consent to Participate:

583 All the authors have personel consent to perform the completion of manuscript. No any authors 584 is forced to perform the work. All the manuscript is mutually cooperated by authors.

585 Author's Contribution:

586 Mr. Arsalan Tanveer: Complete writing, Data analysis, Software working, Econometric 587 modeling, Methodology. Professor Dr Huaming Song: Supervision, Conceptualization. Dr. 588 Muhammad Faheem: Software working, Mathematical investigation, revision and verification 589 of the analysis. Mr.Abdul Daud: Proofreading, Methodology review. Miss Saira Naseer: 590 Review, editing, references verification, and resources verification.

$591 \quad$ Funding Source:

592 No funding source is avialble for this manuscript. 
Availability of Data and materials:

594

All the data is obtained through online data base system, the links are mentioned in the refernces section. Also any material and data required will be available for journal of ESPR on request.

596

597

598

599

600

601

602

603

604

605

606

607

608

609

610

611

612

613

614

615

616

617

618

619

620

621

622

623

624

625

626

627

628

629

630

631

632

633

634

635

\section{Author's Position:}

Mr. ArsalanTanveer is PhD Scholar at the School of Economics and Management, Nanjing University of Science and Technology P.R China 210094.

Professor Dr Huaming Song is working as a professor at the School of Economics and Management, Nanjing University of Science and Technology P.R China 210094.

Dr Muhammad Faheem is working as Assistant Professor at the School of Economics, BahauddinZakariya University, Multan Pakistan.

Mr. AbdulDaud is PhD Scholar at the School of Economics and Management, Nanjing University of Science and Technology P.R China 210094.

Miss SairaNaseer is PhD Scholar at the School of Economics and Management, Nanjing University of Science and Technology P.R China 210094.

\section{REFERENCES:}

Abas, N., Kalair, A., Khan, N., \& Kalair, A. R. (2017). Review of GHG emissions in Pakistan compared to SAARC countries. Renewable and Sustainable Energy Reviews, 80(January 2016), 990-1016. https://doi.org/10.1016/j.rser.2017.04.022

Abbasi, F., \& Riaz, K. (2016). CO 2 emissions and financial development in an emerging economy: An augmented VAR approach. Energy Policy, 90, 102-114. https://doi.org/10.1016/j.enpol.2015.12.017

Acheampong, A. O., Adams, S., \& Boateng, E. (2019). Do globalization and renewable energy contribute to carbon emissions mitigation in Sub-Saharan Africa? Science of the Total Environment, 677, 436-446. https://doi.org/10.1016/j.scitotenv.2019.04.353

Ahmad, A., Zhao, Y., Shahbaz, M., Bano, S., Zhang, Z., Wang, S., \& Liu, Y. (2016). Carbon emissions, energy consumption and economic growth: An aggregate and disaggregate analysis of the Indian economy. Energy Policy, 96, 131-143. https://doi.org/10.1016/j.enpol.2016.05.032

Ahmad, Manzoor, Khan, Z., Rahman, Z. U., \& Khan, S. (2019). Does financial development asymmetrically affect $\mathrm{CO} 2$ emissions in China? An application of the nonlinear autoregressive distributed lag ( NARDL ) model. Carbon Management, 9(6), 631-644. https://doi.org/10.1080/17583004.2018.1529998

Ahmad, Munir, \& Zhao, Z. Y. (2018). Empirics on linkages among industrialization, urbanization, energy consumption, $\mathrm{CO} 2$ emissions and economic growth: a heterogeneous panel study of China. Environmental Science and Pollution Research, 25(30), 3061730632. https://doi.org/10.1007/s11356-018-3054-3

Ahmad, N., \& Du, L. (2017). Effects of energy production and CO2 emissions on economic growth in Iran: ARDL approach. Energy, 123, 521-537. https://doi.org/10.1016/j.energy.2017.01.144

Akalpler, E., \& Hove, S. (2019). Carbon emissions, energy use, real GDP per capita and trade matrix in the Indian economy-an ARDL approach. Energy, 168, 1081-1093. https://doi.org/10.1016/j.energy.2018.12.012

Ali, H. S., Zeqiraj, V., Lin, W. L., Law, S. H., Yusop, Z., Bare, U. A. A., \& Chin, L. (2019). 
Does quality institutions promote environmental quality? Environmental Science and Pollution Research, 10446-10456. https://doi.org/10.1007/s11356-019-04670-9

Ali, M. U., Gong, Z., Ali, M. U., Wu, X., \& Yao, C. (2020). Fossil energy consumption, economic development, inward FDI impact on CO2 emissions in Pakistan: Testing EKC hypothesis through ARDL model. International Journal of Finance and Economics, (June), 1-12. https://doi.org/10.1002/ijfe.1958

Ali, R., Bakhsh, K., \& Yasin, M. A. (2019a). Impact of urbanization on CO 2 emissions in emerging economy : Evidence from Pakistan. Sustainable Cities and Society, 48(March), 101553. https://doi.org/10.1016/j.scs.2019.101553

Ali, R., Bakhsh, K., \& Yasin, M. A. (2019b). Impact of urbanization on CO 2 emissions in emerging economy: Evidence from Pakistan. Sustainable Cities and Society, 48(December 2018), 101553. https://doi.org/10.1016/j.scs.2019.101553

Anser, M. K. (2019). Impact of energy consumption and human activities on carbon emissions in Pakistan : application of STIRPAT model Impact of energy consumption and human activities on carbon emissions in Pakistan : application of STIRPAT model. Environmental Science and Pollution Research, (November). https://doi.org/10.1007/s11356-019-04859-y

Ashraf, A., Khalid, M., \& Cui, S. (2017). Exploring environmental Kuznets curve ( EKC ) in relation to green revolution: A case study of Pakistan. Environmental Science and Policy, 77(August), 166-171. https://doi.org/10.1016/j.envsci.2017.08.019

Attari, M. I. J., Hussain, M., \& Javid, A. Y. (2016). Carbon emissions and industrial growth: an ARDL analysis for Pakistan. International Journal of Energy Sector Management, 10(4), 642-658. https://doi.org/10.1108/IJESM-04-2014-0002

Bakhsh, K., Rose, S., Ali, M. F., Ahmad, N., \& Shahbaz, M. (2017). Economic growth, CO2 emissions, renewable waste and FDI relation in Pakistan: New evidences from 3SLS. Journal of Environmental Management, 196, 627-632. https://doi.org/10.1016/j.jenvman.2017.03.029

Baloch, M. A., \& Suad, S. (2018). Modeling the impact of transport energy consumption on CO 2 emission in Pakistan : Evidence from ARDL approach. Environmental Science and Pollution Research, (2009). Retrieved from https://doi.org/10.1007/s11356-018-1230-0

Balsalobre-lorente, D., Gokmenoglu, K. K., Taspinar, N., \& Cantos-cantos, J. M. (2019). An approach to the pollution haven and pollution halo hypotheses in MINT countries. Environmental Science and Pollution Research, 23010-23026. Retrieved from Springer Nature

Banerjee, A., Dolado, J. J., \& Mestre, R. (1998). Error-correction mechanism tests for cointegration in a single-equation framework. Journal of Time Series Analysis, 19(3), 267283. https://doi.org/10.1111/1467-9892.00091

Baz, K., Deyi, X., Minua, G., Ampofo, K., Ali, I., \& Khan, I. (2019). Energy consumption and economic growth nexus: New evidence from Pakistan using asymmetric analysis. Energy, (C) 2019 Pub. https://doi.org/10.1016/j.energy.2019.116254

Brown, R. L., Durbin, J., \& Evans, J. M. (1975). Techniques for Testing the Constancy of Regression Relationships Over Time. Journal of the Royal Statistical Society: Series B (Methodological), 37(2), 149-163. https://doi.org/10.1111/j.2517-6161.1975.tb01532.x

Buhari, D. O. Ğ. A. N., Lorente, D. B., \& Ali Nasir, M. (2020). European commitment to COP21 and the role of energy consumption, FDI, trade and economic complexity in sustaining economic growth. Journal of Environmental Management, 273(January), 111146. https://doi.org/10.1016/j.jenvman.2020.111146 
Chandia, K. E., Gul, I., Aziz, S., Sarwar, B., \& Zulfiqar, S. (2018). An analysis of the association among carbon dioxide emissions, energy consumption and economic performance: an econometric model. Carbon Management, 9(3), 227-241. https://doi.org/10.1080/17583004.2018.1457930

Chang, M. C., Hu, J. L., \& Jan, F. G. (2016). Performance estimation of energy consumption and carbon dioxide emissions for sustainable development in Baltic Sea countries. Journal of Cleaner Production, 139, 1370-1382. https://doi.org/10.1016/j.jclepro.2016.09.006

Demir, F., \& Duan, Y. (2018). Bilateral FDI Flows, Productivity Growth, and Convergence : The North vs . The South. World Development, 101, 235-249. https://doi.org/10.1016/j.worlddev.2017.08.006

Destek, M. A., \& Okumus, I. (2019). Does pollution haven hypothesis hold in newly industrialized countries? Evidence from ecological footprint. Environmental Science and Pollution Research, 26(23), 23689-23695. https://doi.org/10.1007/s11356-019-05614-z

Du, K., \& Li, J. (2019). Towards a green world: How do green technology innovations affect total-factor carbon productivity. Energy Policy, 131(December 2018), 240-250. https://doi.org/10.1016/j.enpol.2019.04.033

Economic Survey of Pakistan, C. C. P. (2019). Bureau of Statistics Pakistan. Retrieved from www.finance.gov.pk > survey_1819

Faheem, M., \& Chin, L. (2021). Does oil price spur public expenditures in Saudi Arabia , Kuwait and United Arab Emirates? Wiley Online Library, (September 2020), 1-18. https://doi.org/10.1002/pa.2604

Gao, T., Shen, L., Shen, M., Liu, L., Chen, F., \& Gao, L. (2017). Evolution and projection of CO2 emissions for China's cement industry from 1980 to 2020. Renewable and Sustainable Energy Reviews, 74(February 2017), 522-537. https://doi.org/10.1016/j.rser.2017.02.006

Granger, Y. (2002). HIDDEN COINTEGRATION. In Hidden Cointegration in ARDL and ARDL Approach (Vol. 0508).

Griffin, P. W., \& Hammond, G. P. (2019). Industrial energy use and carbon emissions reduction in the iron and steel sector: A UK perspective. Applied Energy, 249(January), 109-125. https://doi.org/10.1016/j.apenergy.2019.04.148

Hdom, H. A. D., \& Fuinhas, J. A. (2020). Energy production and trade openness: Assessing economic growth, $\mathrm{CO} 2$ emissions and the applicability of the cointegration analysis. Energy Strategy Reviews, 30. https://doi.org/10.1016/j.esr.2020.100488

Hussain, S. J., \& Ur, M. (2014). Munich Personal RePEc Archive Do Economic and Financial Development Increase Carbon Emission in Pakistan : Empirical Analysis through ARDL Cointegration and VECM Causality. Munich Personal RePEc Archive, (60310). Retrieved from https://mpra.ub.uni-muenchen.de/60310/

IEA. (2019). IEA. Retrieved from CO2 emission from Fuels Combustions: Highlights. IEA statistics, Inter- national energy agency, OECD, Paris. website: https://www.iea.org/reports/world-energy-outlook-2019

Javid, M., \& Sharif, F. (2016). Environmental Kuznets curve and financial development in Pakistan. Renewable and Sustainable Energy Reviews, 54, 406-414. https://doi.org/10.1016/j.rser.2015.10.019

Jawad, S., Shahzad, H., Kumar, R. R., Zakaria, M., \& Hurr, M. (2017). crossmark. Renewable and Sustainable Energy Reviews, 70(November 2015), 185-192. https://doi.org/10.1016/j.rser.2016.11.042

Jawad, S., Shahzad, H., Ravinesh, R., \& Zakaria, M. (2017). Carbon emission , energy 
consumption, trade openness and fi nancial development in Pakistan : A revisit. Renewable and Sustainable Energy Reviews, 70(November 2015), 185-192. https://doi.org/10.1016/j.rser.2016.11.042

Kamran, M., Teng, J., Imran, M., \& Owais, M. (2019). Science of the Total Environment Impact of globalization, economic factors and energy consumption on CO 2 emissions in Pakistan. Science of the Total Environment, 688, 424-436. https://doi.org/10.1016/j.scitotenv.2019.06.065

Kasman, A., \& Duman, Y. S. (2015). CO2 emissions, economic growth, energy consumption, trade and urbanization in new EU member and candidate countries: A panel data analysis. Economic Modelling, 44, 97-103. https://doi.org/10.1016/j.econmod.2014.10.022

Kevin P. Gallagher. (2008). Handbook on Trade and the Environment (U. Kevin P. Gallagher, Professor of Global Development Policy and Director, Global Development Policy Center, Boston University, Ed.). https://doi.org/368 pp

Khan, A., Chenggang, Y., Xue Yi, W., Hussain, J., Sicen, L., \& Bano, S. (2020). Examining the pollution haven, and environmental kuznets hypothesis for ecological footprints: an econometric analysis of China, India, and Pakistan. Journal of the Asia Pacific Economy, O(0), 1-21. https://doi.org/10.1080/13547860.2020.1761739

Komal, R., \& Abbas, F. (2015). Linking financial development, economic growth and energy consumption in Pakistan. Renewable and Sustainable Energy Reviews, 44, 211-220. https://doi.org/10.1016/j.rser.2014.12.015

Le, H. P., \& Ozturk, I. (2020). The impacts of globalization, financial development, government expenditures, and institutional quality on $\mathrm{CO} 2$ emissions in the presence of environmental Kuznets curve. Environmental Science and Pollution Research, 27(18), 22680-22697. https://doi.org/10.1007/s11356-020-08812-2

Le, T. H., Chang, Y., \& Park, D. (2016). Trade openness and environmental quality: International evidence. Energy Policy, 92, 45-55. https://doi.org/10.1016/j.enpol.2016.01.030

Lin, B., \& Ahmad, I. (2017). Analysis of energy related carbon dioxide emission and reduction potential in Pakistan. Journal of Cleaner Production. https://doi.org/10.1016/j.jclepro.2016.12.113

Lin, B., Moubarak, M., \& Ouyang, X. (2014). Carbon dioxide emissions and growth of the manufacturing sector : Evidence for China. Energy, 76(2014), 830-837. https://doi.org/10.1016/j.energy.2014.08.082

Lin, B., \& Raza, M. Y. (2019). Analysis of energy related CO 2 emissions in Pakistan. Journal of Cleaner Production, 219, 981-993. https://doi.org/10.1016/j.jclepro.2019.02.112

Lin, B., \& Yousaf, M. (2020). Energy substitution effect on transport sector of Pakistan : A translog production function approach. Journal of Cleaner Production, 251, 119606. https://doi.org/10.1016/j.jclepro.2019.119606

Liu, M., Ren, X., Cheng, C., \& Wang, Z. (2020). The role of globalization in CO2 emissions: A semi-parametric panel data analysis for G7. Science of the Total Environment, 137379. https://doi.org/10.1016/j.scitotenv.2020.137379

Ma, X., Wang, C., Dong, B., Gu, G., Chen, R., Li, Y., ... Li, Q. (2019). Carbon emissions from energy consumption in China: Its measurement and driving factors. Science of the Total Environment, 648(27), 1411-1420. https://doi.org/10.1016/j.scitotenv.2018.08.183

Mahmood, H., Alkhateeb, T. T. Y., \& Furqan, M. (2020). Industrialization, urbanization and CO2 emissions in Saudi Arabia: Asymmetry analysis. Energy Reports, 6, 1553-1560. 
https://doi.org/10.1016/j.egyr.2020.06.004

Malik, M. Y., Latif, K., Khan, Z., Butt, H. D., Hussain, M., \& Nadeem, M. A. (2020). Symmetric and asymmetric impact of oil price, FDI and economic growth on carbon emission in Pakistan: Evidence from ARDL and non-linear ARDL approach. Science of the Total Environment, 726(April), 138421. https://doi.org/10.1016/j.scitotenv.2020.138421

Marques, C. (2020). Rediscovering the EKC hypothesis for the 20 highest CO 2 emitters among OECD countries by level of globalization. International Economics Elesvier, 164(June), 36-47. https://doi.org/10.1016/j.inteco.2020.07.001

Mehmood, U. (2020). Globalization and CO 2 emissions nexus : evidence from the EKC hypothesis in South Asian countries. Environmental Science and Pollution Research.

Meng, G., Guo, Z., \& Li, J. (2021). The dynamic linkage among urbanisation, industrialisation and carbon emissions in China: Insights from spatiotemporal effect. Science of the Total Environment, 760, 144042. https://doi.org/10.1016/j.scitotenv.2020.144042

Mirza, F. M., \& Kanwal, A. (2017). Energy consumption, carbon emissions and economic growth in Pakistan : Dynamic causality analysis. Renewable and Sustainable Energy Reviews, 72(May 2011), 1233-1240. https://doi.org/10.1016/j.rser.2016.10.081

Narayan, P. K. (2005). The saving and investment nexus for China: Evidence from cointegration tests. Applied Economics, 37(17), 1979-1990. https://doi.org/10.1080/00036840500278103

Nathaniel, S., Aguegboh, E., Iheonu, C., Sharma, G., \& Shah, M. (2020). Energy consumption, FDI, and urbanization linkage in coastal Mediterranean countries: re-assessing the pollution haven hypothesis. Environmental Science and Pollution Research, 27(28), 35474-35487. https://doi.org/10.1007/s11356-020-09521-6

Ouattara, B. (2004). The Impact of Project Aid and Programme Aid Inflows on Domestic Savings: a Case Study of Côte d'Ivoire. School of Economic Studies, University of Manchester, UK, 44(1-12).

Pata, U. K. (2018). The effect of urbanization and industrialization on carbon emissions in Turkey: evidence from ARDL bounds testing procedure. Environmental Science and Pollution Research, 25(8), 7740-7747. https://doi.org/10.1007/s11356-017-1088-6

Pesaran, M. H. (2014). EMPIRICAL TESTS OF THE POLLUTION HAVEN HYPOTHESIS WHEN ENVIRONMENTAL REGULATION IS ENDOGENOUS. JOURNAL OF APPLIED ECONOMETRICS, 21(August 2012), 1-21. https://doi.org/10.1002/jae

Pesaran, Y. S. and Ri. J. S. (2001). BOUNDS TESTING APPROACHES TO THE ANALYSIS. Econometric Methods and Applications, 326(February), 289-326. https://doi.org/10.1002/jae.616

Pethig, R. (1976). Pollution, welfare, and environmental policy in the theory of Comparative Advantage. Journal of Environmental Economics and Management, 2(3), 160-169. https://doi.org/10.1016/0095-0696(76)90031-0

Qureshi, M. I., Awan, U., Arshad, Z., Rasli, A. M., Zaman, K., \& Khan, F. (2016). Dynamic linkages among energy consumption, air pollution, greenhouse gas emissions and agricultural production in Pakistan: sustainable agriculture key to policy success. Natural Hazards, 84(1), 367-381. https://doi.org/10.1007/s11069-016-2423-9

Rahman, M. M., Saidi, K., \& Mbarek, M. Ben. (2020). Economic growth in South Asia: the role of $\mathrm{CO} 2$ emissions, population density and trade openness. Heliyon, 6(5). https://doi.org/10.1016/j.heliyon.2020.e03903

Rasool, Y., Anees, S., Zaidi, H., \& Zafar, M. W. (2019). Determinants of carbon emissions in Pakistan' s transport sector. Environmental Science and Pollution Research. Retrieved 

from https://doi.org/10.1007/s11356-019-05504-4

Rehermann, F., \& Pablo-Romero, M. (2018). Economic growth and transport energy consumption in the Latin American and Caribbean countries. Energy Policy, 122(July), 518-527. https://doi.org/10.1016/j.enpol.2018.08.006

Repkine, A., \& Min, D. (2020). Foreign-Funded Enterprises and Pollution Halo Hypothesis : A Spatial Econometric Analysis of Thirty Chinese Regions. Sustainability MDPI.

Shahbaz, M., Balsalobre-Lorente, D., \& Sinha, A. (2019). Foreign direct Investment-CO 2 emissions nexus in Middle East and North African countries: Importance of biomass energy consumption. Journal of Cleaner Production, 217, 603-614. https://doi.org/10.1016/j.jclepro.2019.01.282

Shahbaz, M., Gozgor, G., Adom, P. K., \& Hammoudeh, S. (2019). The technical decomposition of carbon emissions and the concerns about FDI and trade openness effects in the United States. International Economics, 159(May), 56-73. https://doi.org/10.1016/j.inteco.2019.05.001

Shahbaz, M., Jawad, S., Shahzad, H., \& Mahalik, M. K. (2017). Is Globalization Detrimental to CO 2 Emissions in Japan? New Threshold Analysis. Environmental Model Access Springer Nature.

Shahbaz, M., Kumar, M., Jawad, S., \& Shahzad, H. (2019). Testing the globalization-driven carbon emissions hypothesis : International evidence. International Economics, 158(February), 25-38. https://doi.org/10.1016/j.inteco.2019.02.002

Shahbaz, M., Nasreen, S., Ahmed, K., \& Hammoudeh, S. (2017). Trade openness-carbon emissions nexus: The importance of turning points of trade openness for country panels. Energy Economics, 61, 221-232. https://doi.org/10.1016/j.eneco.2016.11.008

Shahzad, S. J. H., Kumar, R. R., Zakaria, M., \& Hurr, M. (2017). Carbon emission, energy consumption, trade openness and financial development in Pakistan: A revisit. Renewable and Sustainable Energy Reviews. https://doi.org/10.1016/j.rser.2016.11.042

Shin, Y., Yu, B., \& Greenwood-nimmo, M. (2014). Modelling Asymmetric Cointegration and Dynamic Multipliers in a Nonlinear ARDL Framework. JOURNAL OF APPLIED ECONOMETRICS. https://doi.org/10.1007/978-1-4899-8008-3

Shujah-ur-Rahman, Chen, S., Saud, S., Bano, S., \& Haseeb, A. (2019). The nexus between financial development, globalization, and environmental degradation: Fresh evidence from Central and Eastern European Countries. Environmental Science and Pollution Research, 26(24), 24733-24747. https://doi.org/10.1007/s11356-019-05714-w

Sun, H., Liu, Z., \& Chen, Y. (2020). Foreign direct investment and manufacturing pollution emissions: A perspective from heterogeneous environmental regulation. Sustainable Development, 28(5), 1376-1387. https://doi.org/10.1002/sd.2091

Tian, Y., Xiong, S., Ma, X., \& Ji, J. (2018). Structural path decomposition of carbon emission: A study of China's manufacturing industry. Journal of Cleaner Production, 193, 563-574. https://doi.org/10.1016/j.jclepro.2018.05.047

Udom, M., Adebola, S., Yorucu, V., Victor, F., \& Asumadu, S. (2020). Modeling natural gas consumption, capital formation, globalization, CO 2 emissions and economic growth nexus in Malaysia : Fresh evidence from combined cointegration and causality analysis. Energy Strategy Reviews, 31, 100526. https://doi.org/10.1016/j.esr.2020.100526

Ulucak, R. (2020). Does information and communication technology affect CO 2 mitigation under the pathway of sustainable development during the mode of globalization? Wiely Online Library, (December 2019), 1-11. https://doi.org/10.1002/sd.2041 
Umar, M., Shahbaz, M., \& Kirikkaleli, D. (2020). Environmental cost of natural resources utilization and economic growth : Can China shift some burden through globalization for sustainable development? Wiely Online Library, 2017(April), 1-11. https://doi.org/10.1002/sd.2116

Ur Rahman, Z., Chongbo, W., \& Ahmad, M. (2019). An (a)symmetric analysis of the pollution haven hypothesis in the context of Pakistan: a non-linear approach. Carbon Management, 10(3), 227-239. https://doi.org/10.1080/17583004.2019.1577179

Vadlamannati, K. C., Â, A. T., \& Pin, J. (2009). Does higher economic and financial development lead to environmental degradation : Evidence from BRIC countries. Energy Policy, 37, 246-253. https://doi.org/10.1016/j.enpol.2008.08.025

Wada, I., Faizulayev, A., Khademolomoom, A. H., \& Alzubi, A. (2020). Energy use, real outputgrowth, FDI, energy-intensity and CO2 emission; the case of Kazakhstan. Journal of Public Affairs, (July). https://doi.org/10.1002/pa.2300

Wang, L., Vinh, X., Shahbaz, M., \& Ak, A. (2020). Globalization and carbon emissions : Is there any role of agriculture value-added, financial development, and natural resource rent in the aftermath of COP21 ? Journal of Environmental Management, 268(March), 110712. https://doi.org/10.1016/j.jenvman.2020.110712

Yang, J., Cheng, J., \& Huang, S. (2020). CO2 emissions performance and reduction potential in China's manufacturing industry: A multi-hierarchy meta-frontier approach. Journal of Cleaner Production, 255, 120226. https://doi.org/10.1016/j.jclepro.2020.120226

You, W., \& Lv, Z. (2018). Spillover effects of economic globalization on CO2 emissions: A spatial panel approach. Energy Economics, \#pagerange\#. https://doi.org/10.1016/j.eneco.2018.05.016

Yousaf, M., \& Lin, B. (2020). Science of the Total Environment Decoupling and mitigation potential analysis of CO 2 emissions from Pakistan's transport sector. Science of the Total Environment, 730, 139000. https://doi.org/10.1016/j.scitotenv.2020.139000

Yu, S., Zheng, S., \& Li, X. (2018). The achievement of the carbon emissions peak in China: The role of energy consumption structure optimization. Energy Economics, 74, 693-707. https://doi.org/10.1016/j.eneco.2018.07.017

Zaidi, S. A. H., Danish, Hou, F., \& Mirza, F. M. (2018). The role of renewable and nonrenewable energy consumption in $\mathrm{CO} 2$ emissions: a disaggregate analysis of Pakistan. Environmental Science and Pollution Research, 25(31), 31616-31629. https://doi.org/10.1007/s11356-018-3059-y

Zaidi, S. A. H., Zafar, M. W., Shahbaz, M., \& Hou, F. (2019). Dynamic linkages between globalization, financial development and carbon emissions: Evidence from Asia Pacific Economic Cooperation countries. Journal of Cleaner Production, 228, 533-543. https://doi.org/10.1016/j.jclepro.2019.04.210

Zakaria, M., \& Bibi, S. (2019). Financial development and environment in South Asia: the role of institutional quality. Environmental Science and Pollution Research, 26(8), 7926-7937. https://doi.org/10.1007/s11356-019-04284-1

Zhang, Bin, \& Wang, Z. (2017). Energy production, economic growth and CO 2 emission : evidence from Pakistan. Natural Hazards. https://doi.org/10.1007/s11069-017-3031-Z

Zhang, Bo, Zhang, Y., Wu, X., Guan, C. H., \& Qiao, H. (2020). How the manufacturing economy impacts China's energy-related GHG emissions: Insights from structural path analysis. Science of the Total Environment, 743, 140769. https://doi.org/10.1016/j.scitotenv.2020.140769 
912 Zhang, Yang, Yan, D., Hu, S., \& Guo, S. (2019). Modelling of energy consumption and carbon 913 emission from the building construction sector in China, a process-based LCA approach. Energy Policy, 134(December 2018), 110949. https://doi.org/10.1016/j.enpol.2019.110949 inflows on China's carbon emissions. Energy Policy, 120(2), 347-353.

Zhu, B., \& Shan, H. (2020). Impacts of industrial structures reconstructing on carbon emission and energy consumption: A case of Beijing. Journal of Cleaner Production, 245, 118916. https://doi.org/10.1016/j.jclepro.2019.118916

921 Zubair, A. O., Abdul Samad, A.-R., \& Dankumo, A. M. (2020). Does gross domestic income, trade integration, FDI inflows, GDP, and capital reduces CO2 emissions? An empirical evidence from Nigeria. Current Research in Environmental Sustainability, 2, 100009. 
Figures

$\mathrm{CO2}$

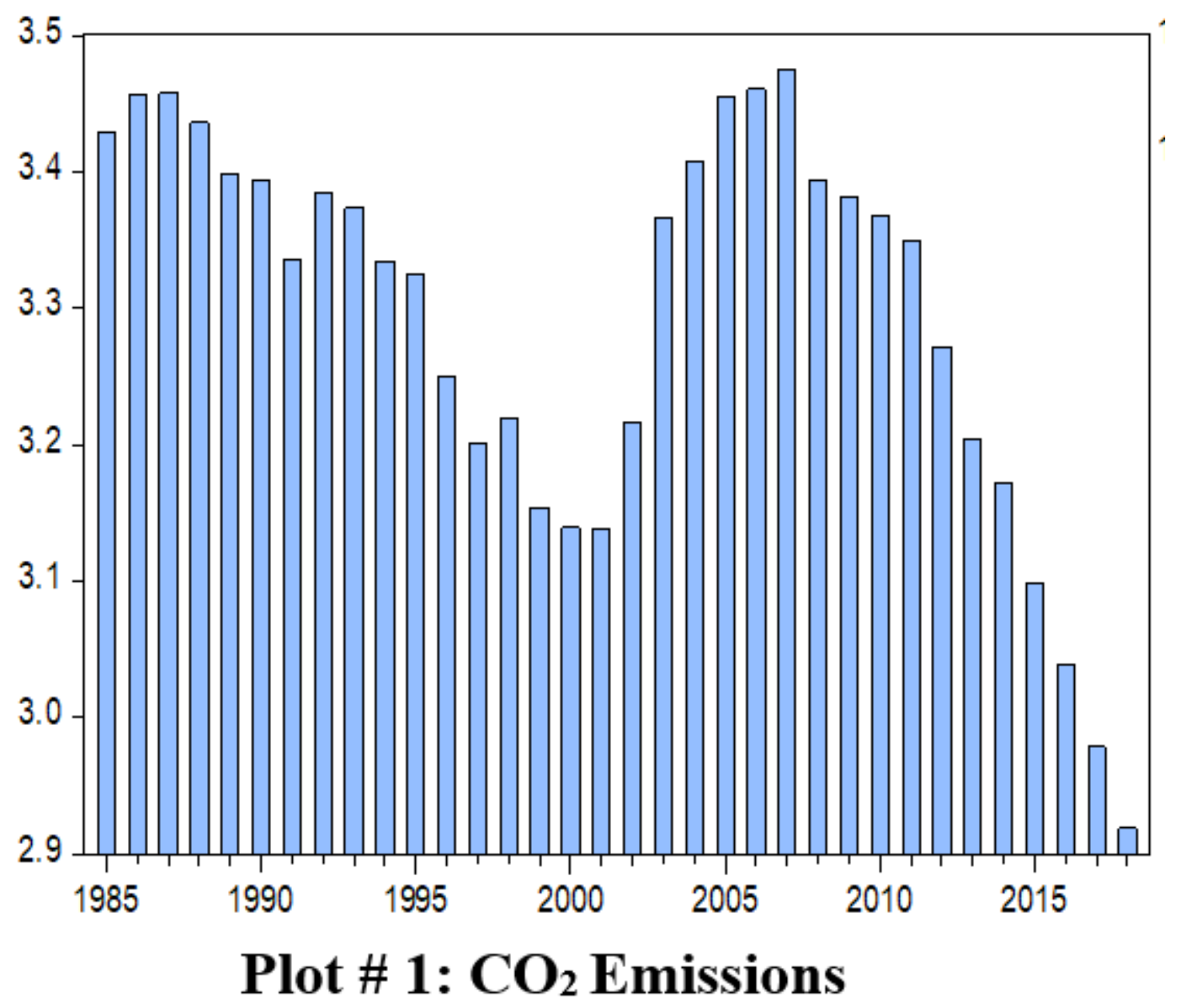

Figure 1

Plot \# 1: CO2 Emissions 


\section{ENR}

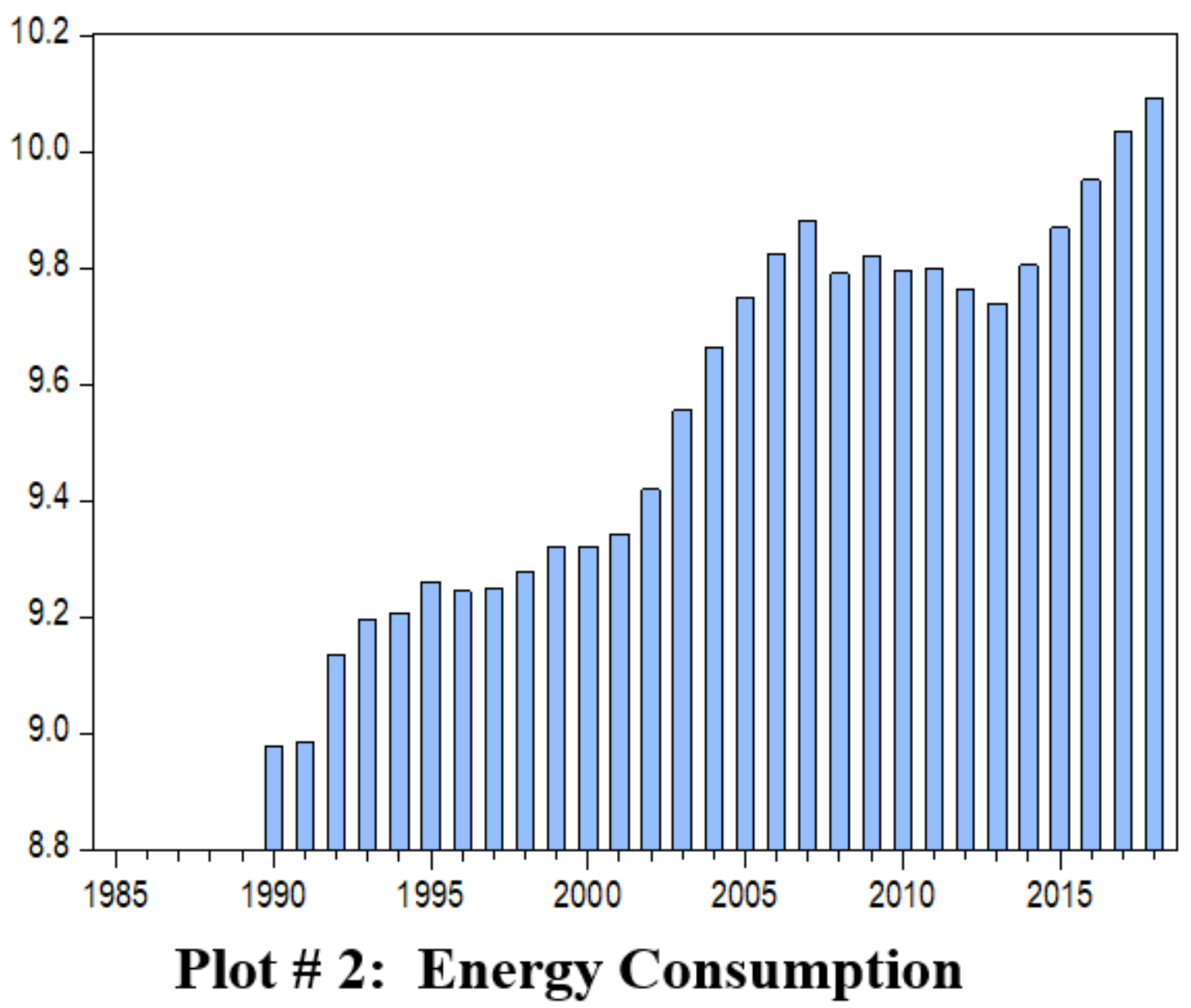

Figure 2

Plot \# 2: Energy Consumption 
FD

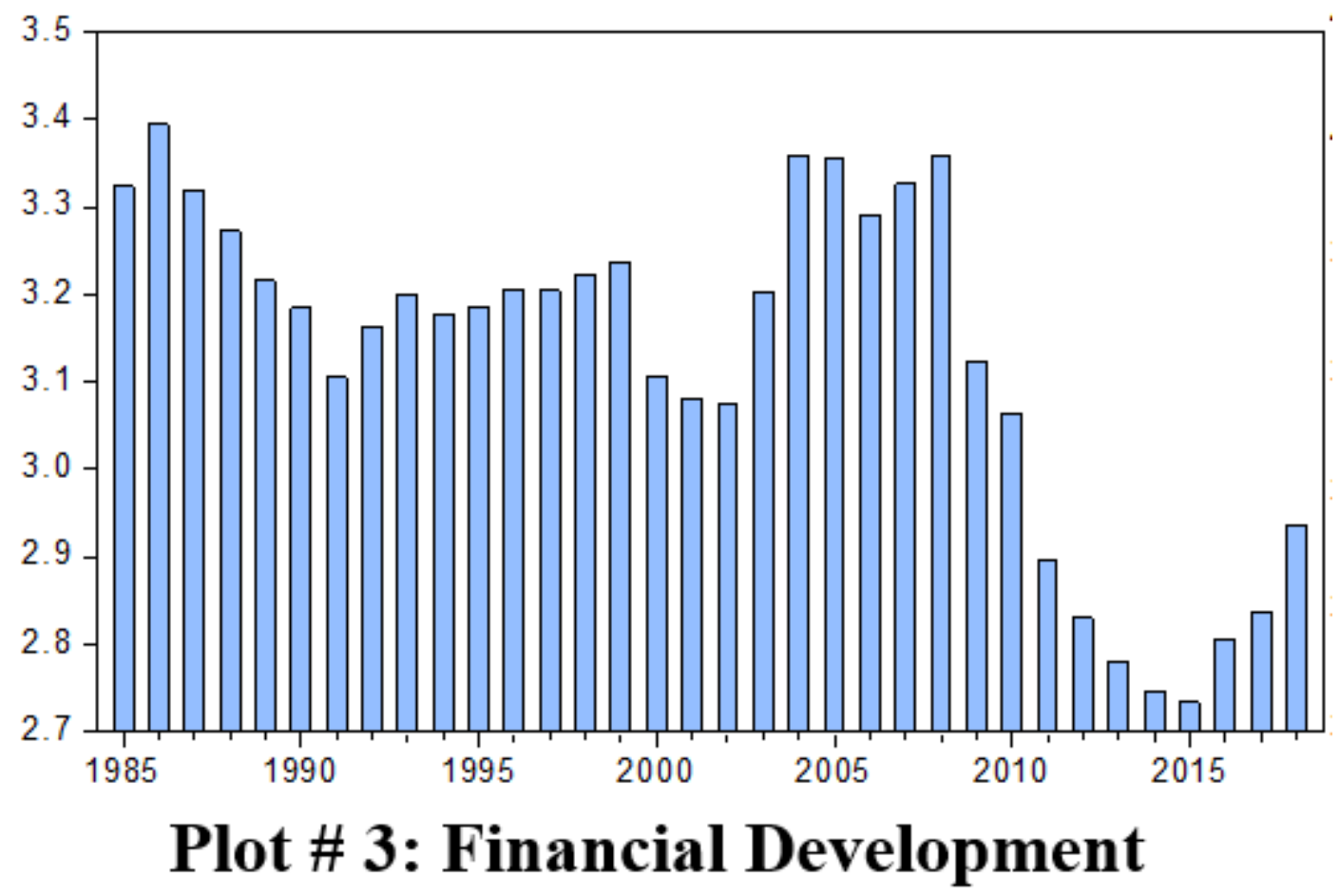

Figure 3

Plot \# 3: Financial Development

Gl

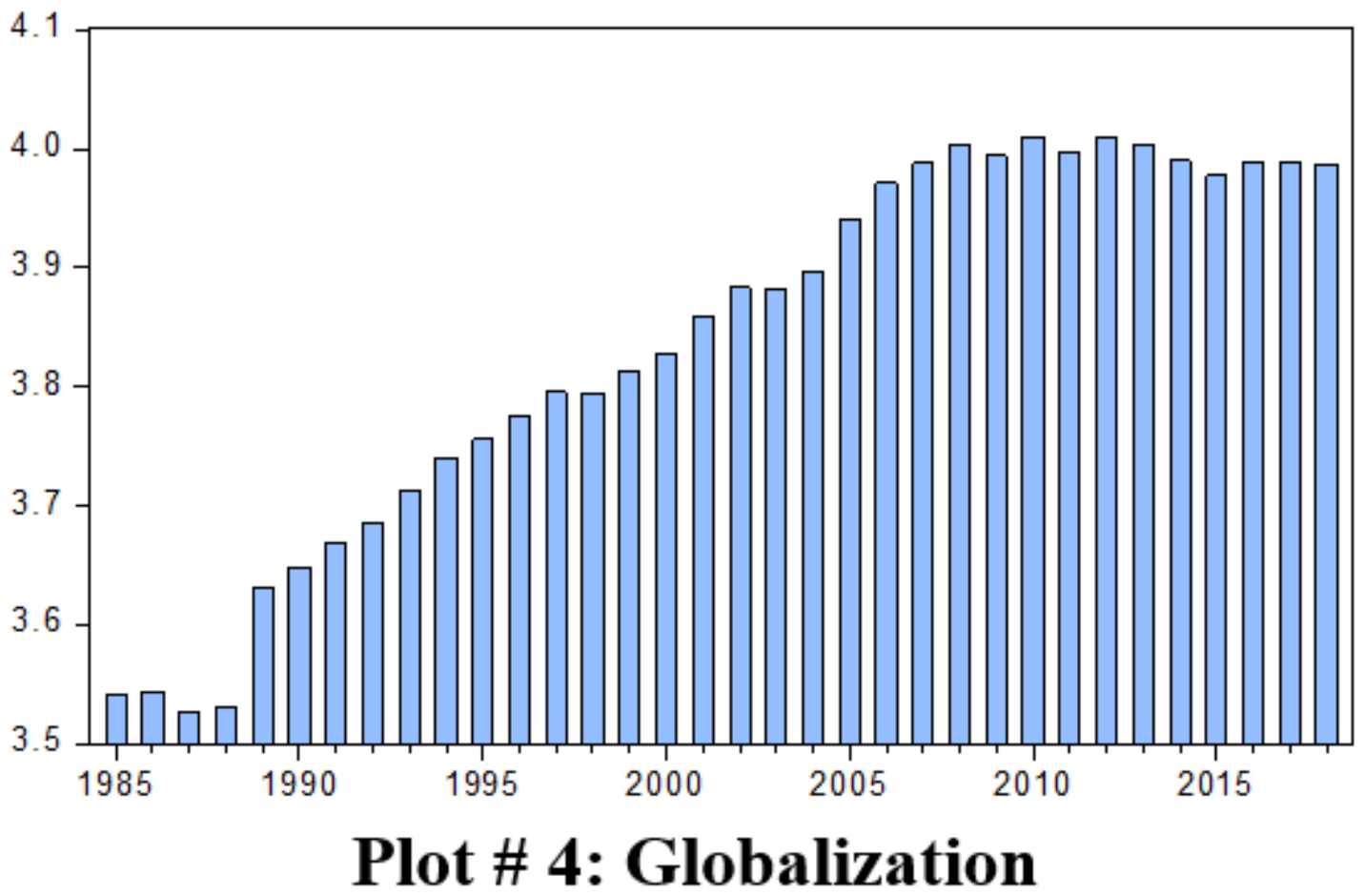


Figure 4

Plot \# 4: Globalization

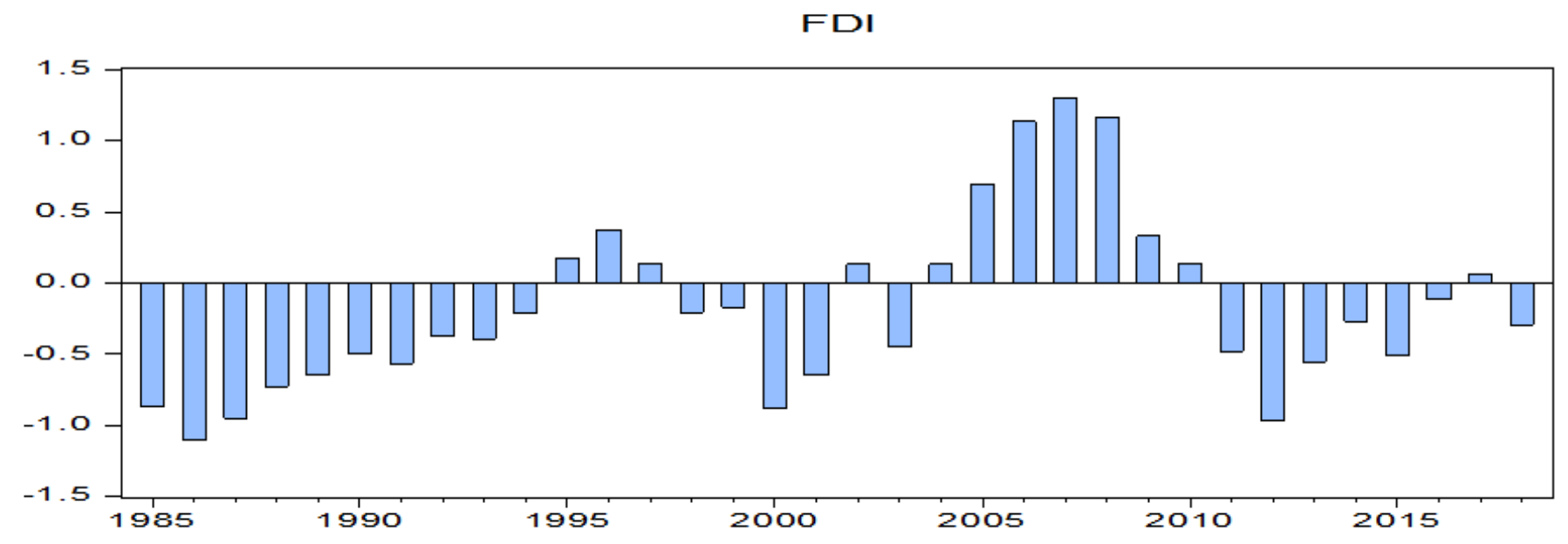

Plot \# 5: Foreign Direct Investment

Figure 5

Plot \# 5: Foreign Direct Investment

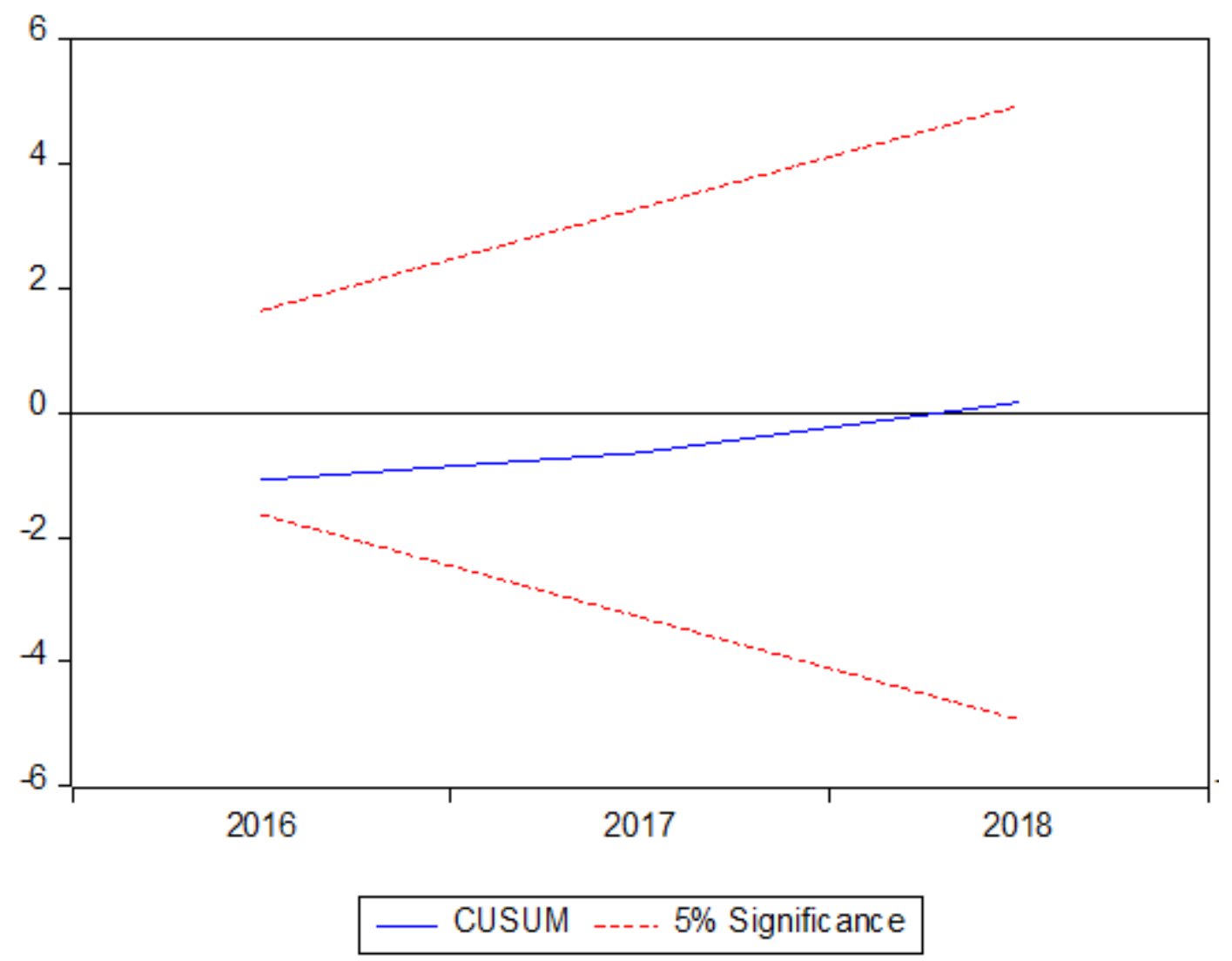

Plot \# 6: CUSUM 
Figure 6

Plot \# 6: CUSUM

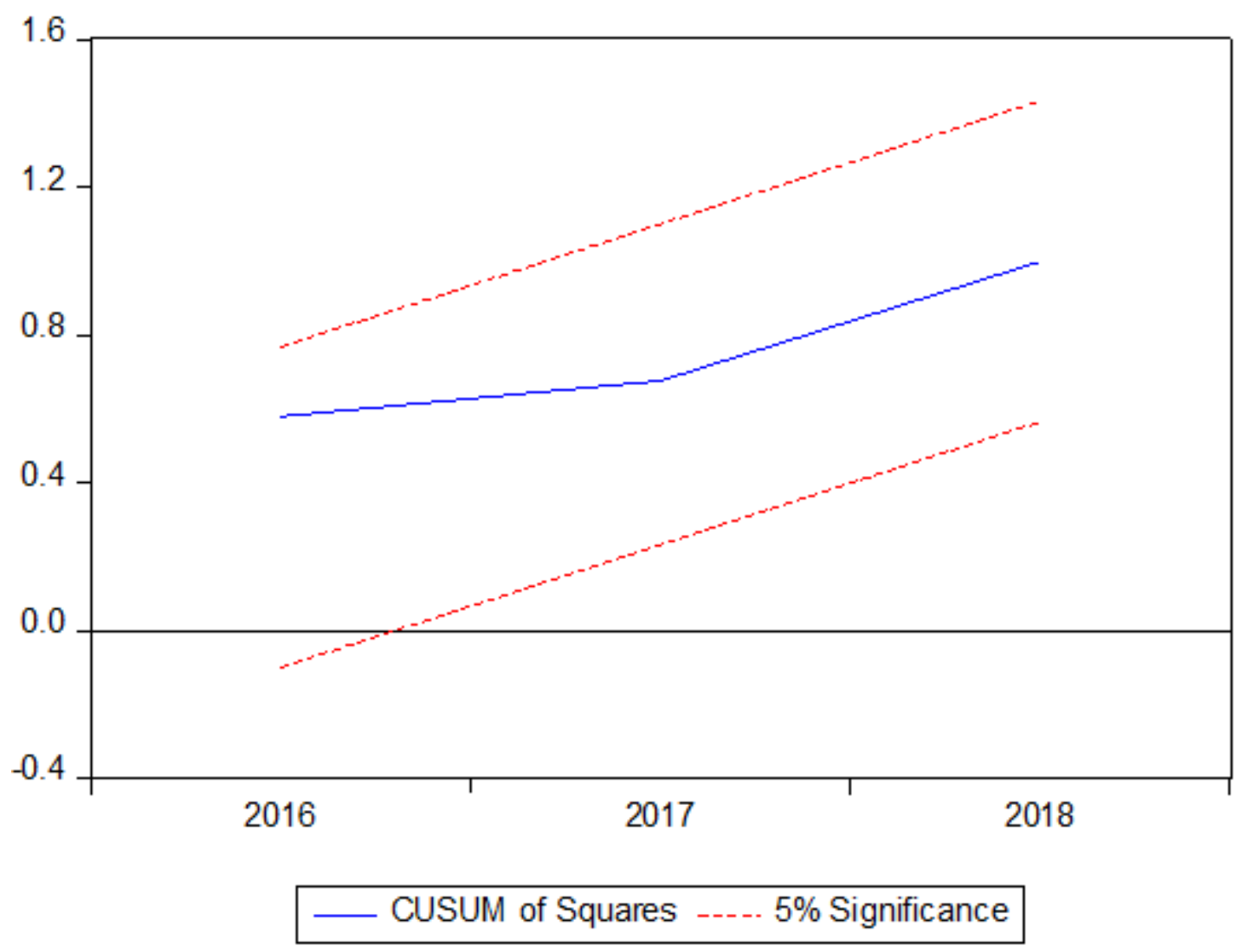

Plot \# 7: CUSUMQ

Figure 7

Plot \# 7: CUSUMQ 


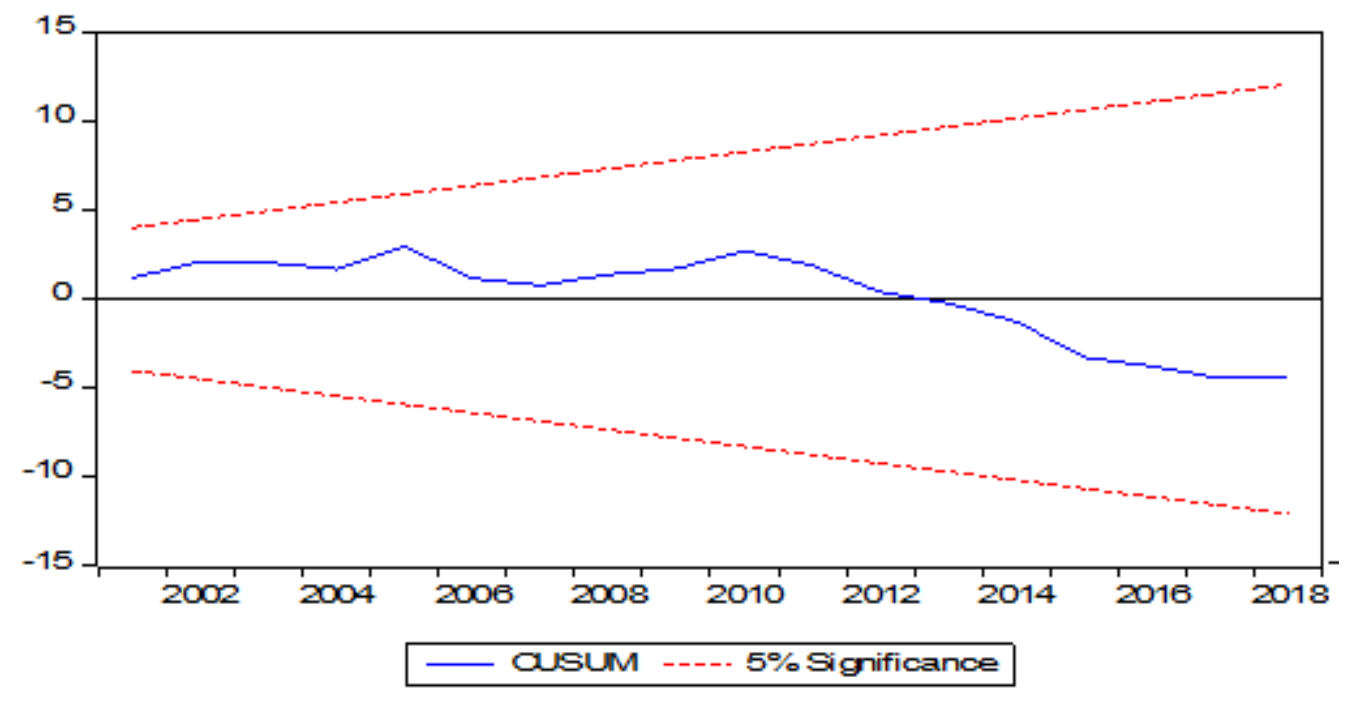

\section{Plot \# 8: CUSUM (NARDL)}

Figure 8

Plot \# 8: CUSUM (NARDL)

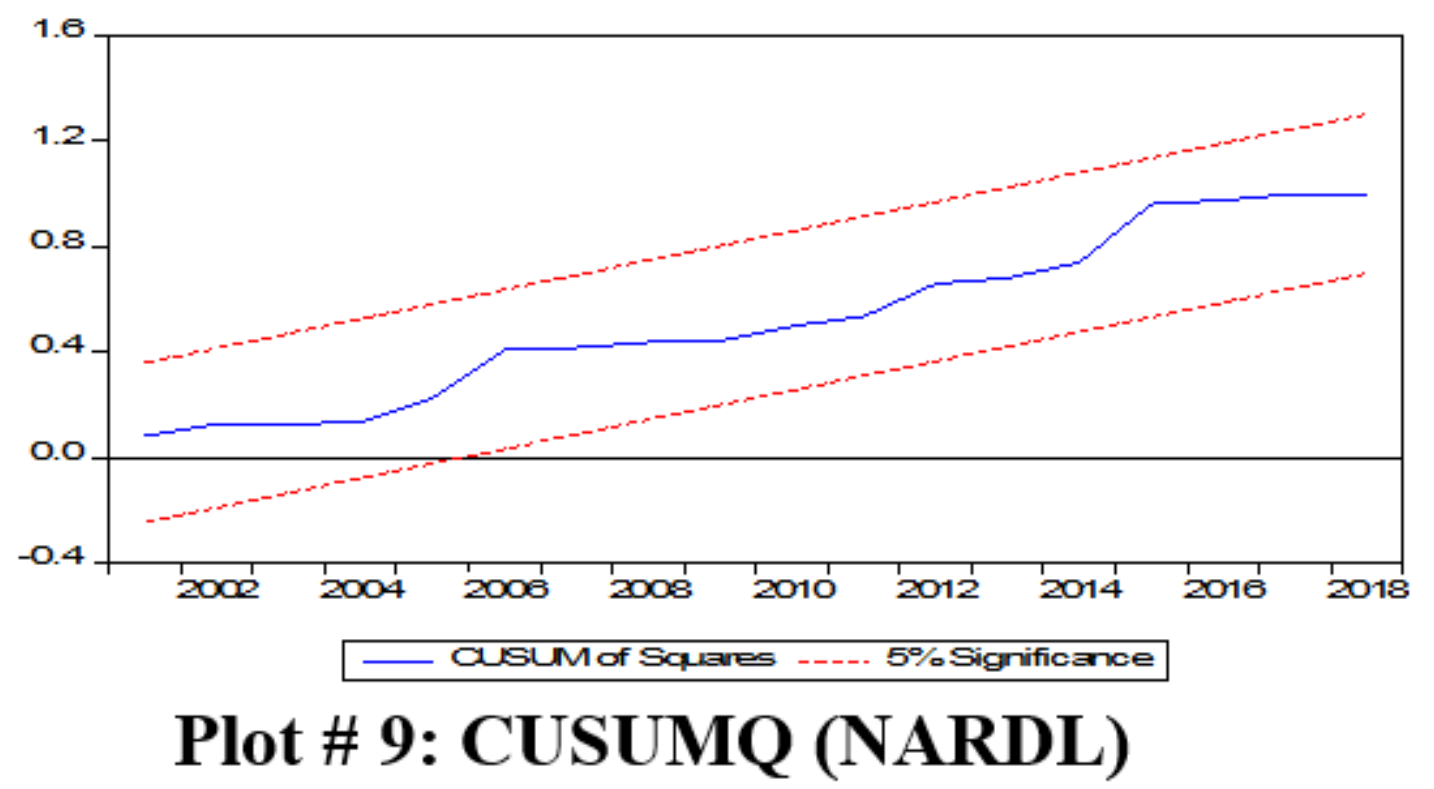

Figure 9

Plot \# 9: CUSUMQ (NARDL) 


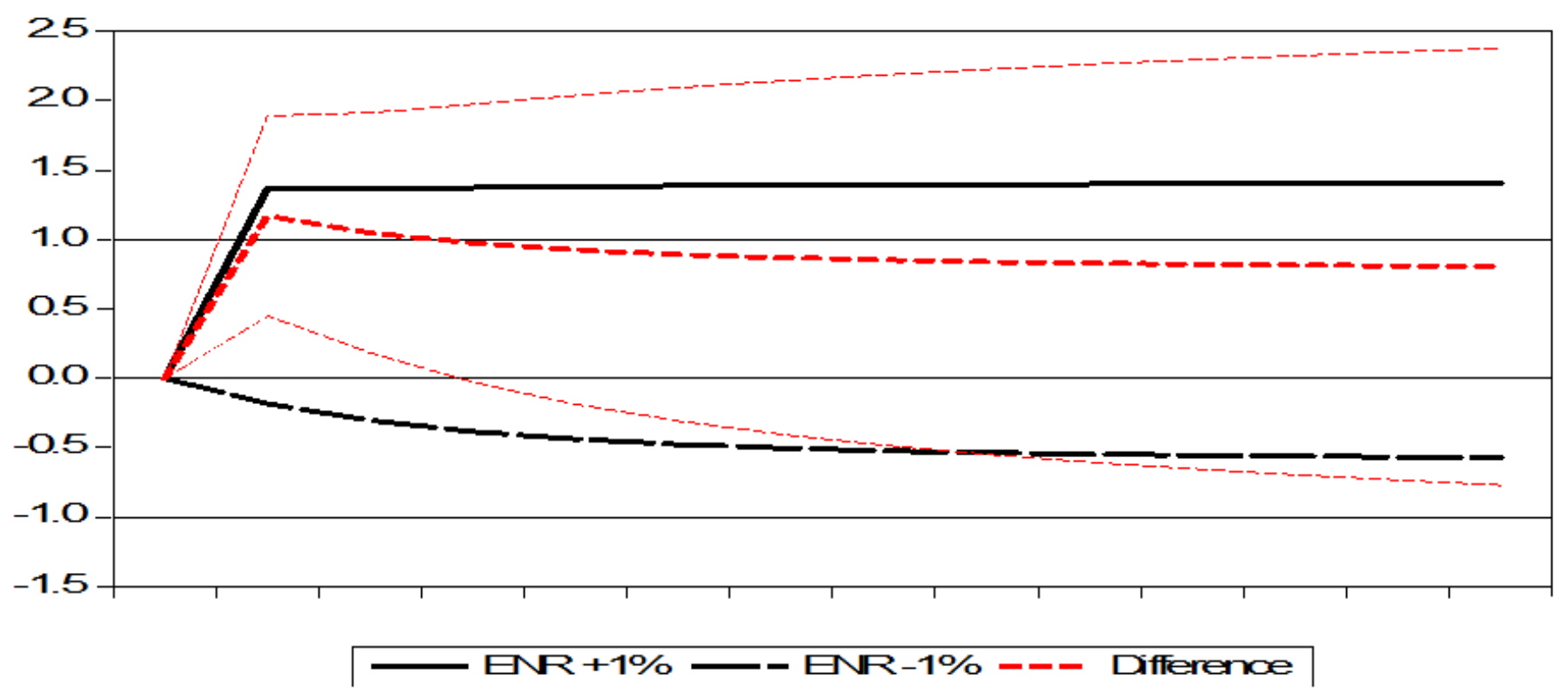

Plot \# 10: Cumulative effects of Energy Consumption on $\mathrm{CO}_{2}$ Emissions.

Figure 10

Plot \# 10: Cumulative effects of Energy Consumption on CO2 Emissions. 